\title{
Fluid-Rock Interactions in a Paleo-Geothermal Reservoir (Noble Hills Granite, California, USA). Part 1: Granite Pervasive Alteration Processes away from Fracture Zones
}

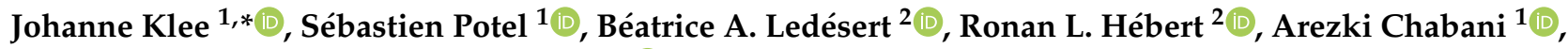 \\ Pascal Barrier ${ }^{1}$ and Ghislain Trullenque ${ }^{1}$ (D) \\ 1 B2R, Geosciences Department, Institut Polytechnique UniLaSalle Beauvais, 19 Rue Pierre Waguet, \\ F-60026 Beauvais, France; sebastien.potel@unilasalle.fr (S.P.); arezki.chabani@unilasalle.fr (A.C.); \\ pascal.barrier@unilasalle.fr (P.B.); ghislain.trullenque@unilasalle.fr (G.T.) \\ 2 Geosciences and Environment Cergy, CY Cergy Paris Université, 1 Rue Descartes, \\ F-95000 Neuville-sur-Oise, France; beatrice.ledesert@cyu.fr (B.A.L.); ronan.hebert@cyu.fr (R.L.H.) \\ * Correspondence: johanne.klee@unilasalle.fr; Tel.: +33-6-06-93-90-07
}

Citation: Klee, J.; Potel, S.; Ledésert, B.A.; Hébert, R.L.; Chabani, A.; Barrier, P.; Trullenque, G. Fluid-Rock Interactions in a Paleo-Geothermal Reservoir (Noble Hills Granite,

California, USA). Part 1: Granite Pervasive Alteration Processes away from Fracture Zones. Geosciences 2021 11, 325. https://doi.org/10.3390/ geosciences 11080325

Academic Editors: Chris Clark and Jesus Martinez-Frias

Received: 18 June 2021

Accepted: 27 July 2021

Published: 31 July 2021

Publisher's Note: MDPI stays neutral with regard to jurisdictional claims in published maps and institutional affiliations.

Copyright: (c) 2021 by the authors. Licensee MDPI, Basel, Switzerland. This article is an open access article distributed under the terms and conditions of the Creative Commons Attribution (CC BY) license (https:/ / creativecommons.org/licenses/by/ $4.0 /)$.

\begin{abstract}
Only few data from geothermal exploited reservoirs are available due to the restricted accessibility by drilling, which limits the understanding of the entire reservoir. Thus, analogue investigations are needed and were performed in the framework of the H2020 MEET project. The Noble Hills range, located along the southern branch of the Death Valley pull-apart (CA, USA), has been selected as a possible granitic paleo-reservoir. The aim is to characterize the pervasive alteration processes affecting this granite, away from the influence of the faults, in terms of mineralogical, petrophysical and chemical changes. Various methods were used as petrographic, geochemical and petrophysical analyses. Mineral changes, clay mineralogy, bulk rock chemical composition, calcite content and porosity were determined on different granite samples, collected in the Noble Hills granite, far from the faults and in the Owlshead Mountains, north of the Noble Hills, considered as its protolith. In order to complete the granite characterization, the metamorphic grade has been studied through the Noble Hills granite body. This complete characterization has allowed distinguishing the occurrence of three stages of alteration: (1) a pervasive propylitic alteration characterized by calcite-corrensite-epidote-K-white mica assemblage, (2) a more local one, only present in the Noble Hills granite, producing illite, kaolinite, illite/smectite, calcite and oxides, characteristic of the argillic alteration, which overprints the propylitic alteration and (3) weathering evidenced by the presence of montmorillonite in the Owlshead Mountains, which is considered as negligible in both granites. Alteration was also outlined by the correlation of the loss on ignition, representing the hydration rate, to porosity, calcite content and chemical composition. Moreover, the Kübler Index calculated from illite crystals allowed to identify a NW-SE temperature gradient in the Noble Hills.
\end{abstract}

Keywords: Noble Hills granite; Owlshead Mountains granite; metamorphic grade; fluid/rock interactions; newly formed minerals; element variations; geothermal reservoir

\section{Introduction}

Geothermal systems occur in different geological settings such as active volcanic fields, plutonic provinces, extensional domains, intracratonic basins and orogenic belts, i.e., anywhere with heat and fluids that are able to flow through the rocks [1]. The exploitation of geothermal energy is expanding worldwide due to the abundant resources and the progress of the technology that lead to Enhanced Geothermal Systems (EGS). EGS (1) defines a reservoir where the natural permeability of the rocks needs to be enhanced through stimulations in order to obtain a sufficient temperature/flow rate ratio [2] and (2) aims at transforming efficiently the geothermal resource into heat and electricity for human consumption [3]. 
The present study is part of the MEET H2020 project (Multidisciplinary and multicontext demonstration of EGS exploration and Exploitation Techniques and potentials) [4]. One aim of this project is to provide a characterization method of a geothermal granitic reservoir in a geological extensive context, such as the Great Basin region (USA), where normal fault zones also act as the most favorable structural setting for geothermal fluid flow [5]. In the Great Basin, other notable structural settings control fluid flow such as the intersection between normal faults and other structures like strike-slip faults $(\sim 22 \%)$, as well as pull-apart structures (4\%) [5]. The fluid-rock interaction along and inside fracture zones results in hydrothermal alterations. They lead to geochemical, mineralogical and petrophysical (porosity and permeability) modifications of the rocks [6]. In granitic rocks, fluid circulations usually occur through the fracture network at different scales $[6,7]$ involving a pervasive alteration which may influence up to cubic kilometers of rock [8]. Thus, an intense fluid/rock interaction [9] can significantly change the mineralogy, the chemistry and the texture of the bulk-rock [7] among which the common formation of clay minerals, including illite. Exploited geothermal reservoirs are located at depth, and the only and limited available data come from drillings (cores, cuttings) and seismic surveys. Studying exhumed geothermal reservoirs allows better understanding of the 3D features of the reservoir. To do so, the Noble Hills range (NH, Death Valley, CA, USA) has been selected as a possible granitic geothermal reservoir in a trans-tensional context. The $\mathrm{NH}$ are located in the southwestern part of the Great Basin region along the Southern Death Valley Fault Zone (SDVFZ), which constitutes the southern branch of the Death Valley pull-apart [10]. They extend over an area of $7 \mathrm{~km}$ long and $2 \mathrm{~km}$ wide and contain a part of the Cretaceous granitic pluton ( $95 \mathrm{Ma}$ ) forming the Owlshead Mountains (OM) [11]. The arid climate prevents from a thick vegetal cover and the deep canyons that crosscut the range allow a thorough $3 \mathrm{D}$ investigation in order to characterize the evolution of the granite at the kilometer scale.

This paper aims at characterizing the pervasive alteration processes affecting the $\mathrm{NH}$ granite. This massif is considered as a possible paleo-geothermal reservoir. The study is based on the analysis of (1) rock mineralogical and related petrophysical properties changes and (2) associated chemical transfers between host rock and percolating fluids. All samples have been collected away from fractures described by [12] (this issue) in order to avoid the influence of strain and massive fluid flow. This sampling strategy ascertains the preservation of the protolith initial magmatic texture and mineralogy. A second paper (Klee et al., this issue) focusses on the role of deformation on hydrothermal alteration close to fractures. Data collected from the $\mathrm{NH}$ granite samples are directly compared to those obtained for the granite samples collected in the OM pluton, which is considered as the protolith. Analyses performed on targeted areas include macroscopic and microscopic petrographic studies, mineralogical characterization by X-ray diffraction (XRD) on whole rock and clay minerals, bulk rock chemical characterization by Inductively Coupled Plasma (ICP)—Mass Spectrometry (MS) and-Atomic Emission Spectrometry (AES), Scanning Electron Microscopy coupled with Energy Dispersive Spectrometry (SEM-EDS) for structural observation and local chemical analyses, as well as calcimetry and porosimetry analyses. To help at the granite characterization, the metamorphic evolution can be estimated through the Kübler Index (KI). Indeed, the temperature range of illite formation can be estimated thanks to the KI $[13,14]$ based on illite "crystallinity" (IC). Temperature is thought to be the main factor controlling the IC evolution, but the lithology also has important effects [15-18]. Working at constant lithology, here granitic rock, allows us to avoid this effect. During the NH range formation, minerals could be transformed similarly as diagenetic reactions observed in feldspathic sandstones [19]. Inoue (1995) [9] has also shown that the rock alteration resulting from hot fluid storage during a long geological period, heated in-situ and in equilibrium with the surrounding rock is usually considered as diagenesis or metamorphism. Therefore, the terms defined by [13] for each diagenetic and metamorphic zones are considered in this study as eligible for granitic context. 


\section{Geological Setting}

\subsection{Death Valley}

The area of interest for this study is the southern part of the Death Valley (DV) region, which extends for about $200 \mathrm{~km}$. It is located southwest of the Basin and Range province [20], in the Eastern California Shear Zone/Walker Lane Belt (ECSZ/WLB) [21-23] (Figure 1a). DV is considered as one of the youngest regions where strike-slip deformation contemporaneously occurs with large-scale crustal extension within the Basin and Range province [24-26]. This extensional basin formation accompanying normal and associated strike-slip faulting would be active since $15 \mathrm{Ma}$ according to [24]. It corresponds to a structural depression between the Panamit Range and the Black and Funeral Mountains [27] (Figure $1 b$ ), generally NNW-SSE oriented. This depression is related to tension along a segment of two strike-slip faults. Those two strike-slip faults consisting in the Northern Death Valley Fault Zone (NDVFZ) and the Southern Death Valley Fault Zone (SDVFZ), are characterized by en echelon traces [28] (Figure 1b). They have a general right-lateral movement, NW-SE oriented, from which results a "pull-apart" structure forming a N-S oriented basin [10] (Figure 1b).

The SDVFZ is composed of several branches. The SDVFZ formed the NH, at its southernmost part, by vertical displacement $[29,30]$ (Figure 2a). It intersects the easttrending left lateral Garlock Fault Zone (GFZ), which ends at its western termination by the northwest-striking San Andreas fault zone [28] (Figure 1a). Recently, [11] suggested a net dextral slip along the SDVFZ of 40-41 km based on the offset positions of the granitebasement contact from the OM to the Avawatz Mountains. Much of the dextral slip, occurring before the deposition of the 6-8 Ma Neogene cover, is indicated by stratigraphic overlaps on fault rocks. This suggests an occurrence of the dextral slip during the main extension. The authors challenge the young feature of the DV pull-apart [25], by opting to a long-lived pull-apart which is consistent with regional evidence of the initiation in the middle Miocene of the dextral trans-tension in the ECSZ/WLB [31].
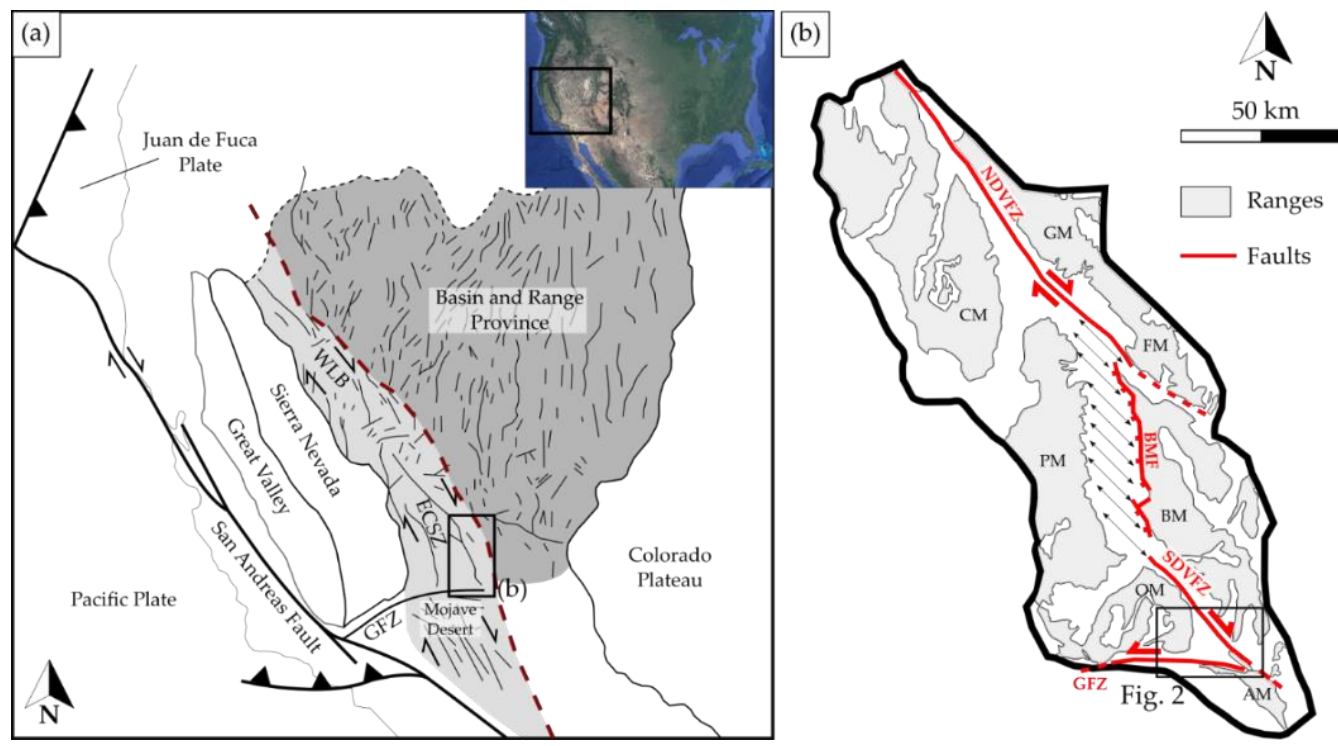

Figure 1. (a) Simplified tectonic map of the Great Basin region (western U.S. Cordillera) showing the tectonic provinces (modified after [32]). WLB—Walker Lane Belt; ECSZ_Eastern California Shear Zone; GFZ_Garlock Fault Zone. The Basin and Range Province is represented in dark grey and the WLB/ECSZ in light grey. The red dashed line marks the limit between these both domains. The dark lines within the Basin and Range Province and in the WLB-ECSZ zone represent the main faults. (b) Structural setting of the Death Valley region (modified after [33,34]. AM-Avawatz Mountains; BM-Black Mountains; BMF—Black Mountains Fault; CM—Cottonwood Mountain; FM—Funeral Mountains; GM-Grapevine Mountains; OM-Owlshead Mountains; PM-Panamint Mountains; GFZ—Garlock Fault Zone; NDVFZ—Northern Death Valley Fault Zone; SDVFZ—Southern Death Valley Fault Zone. 


\subsection{Noble Hills}

The NH extend $14 \mathrm{~km}$ northwest of the northern Avawatz Mountains [30] (Figure 2a,b). A first general geological map of the $\mathrm{NH}$ was provided by [35], and later completed by $[29,36-38]$. They show that Precambrian gneiss covered by Crystal Spring Formation (CSF), a siliclastic-carbonate unit [39] of the Pahrump Group, were first intruded by $1.1 \mathrm{Ga}$ diabase sills then by Mesozoic granitic rocks. All of these facies form the axial crystalline ridge defined by [29].

The NH granite was poorly studied previously. It is part of the calc-alkaline granitoid intrusion related to the emplacement of the Sierra Nevada batholith, which was formed due to the eastward dipping subduction of the Pacific plate under the North American continent [40]. It was only defined as both quartz monzonite [35] and leucocratic adamellite [41] Brady (1986) [29] completed the description as a medium to coarse equigranular grained to slightly porphyritic leucocratic rock containing few biotite and little or no hornblende. The presence of sporadic mineralization due to hydrothermal alteration was also raised by [38]. After the emplacement of the granite and its exhumation, 3.34 Ma Pliocene sediments of the Noble Hills Formation (NHF) were deposited [38]. The NHF consists in interbedded fine-grained clastic and evaporitic rocks, alluvial conglomerates, minor limestone and megabreccia. Recent work done by [42] in the NH has shown a more complex geometry of the axial ridge than described until now (Figure 2c). The undifferentiated Precambrian and Paleozoic rocks facies were described by [42] as a stacking of different CSF series, intruded by the Mesozoic granite. They seem to be dragged and stretched southeastward against the granite following the SDVFZ trend. Tertiary volcanism was also highlighted at the back of the range.

Based on the geology along the SDVFZ trace, Pavlis and Trullenque (2021) [11] suggests that the $\mathrm{NH}$ axial crystalline ridge must be a transported part of the Cretaceous granitic pluton ( $\sim 95 \mathrm{Ma})$, forming the OM [34], which is relatively weakly deformed internally at its southern part [26]. This piece would have moved a minimum of $8 \mathrm{~km}$ according to $[29,37]$ and around $28 \mathrm{~km}$ according to [43] along the SDVFZ (Figure 2b). Brittle shearing and large-scale boudinage characterize a brittle deformation, showing generally subhorizontal axes, which is prevalent within the Cretaceous granitic intrusion and Precambrian roof pendants (Figure 2c). Contractional deformation involving all members of the NHF is characterized along the $\mathrm{NH}$ and increases in intensity southeast toward the intersection with the GFZ [38]. 

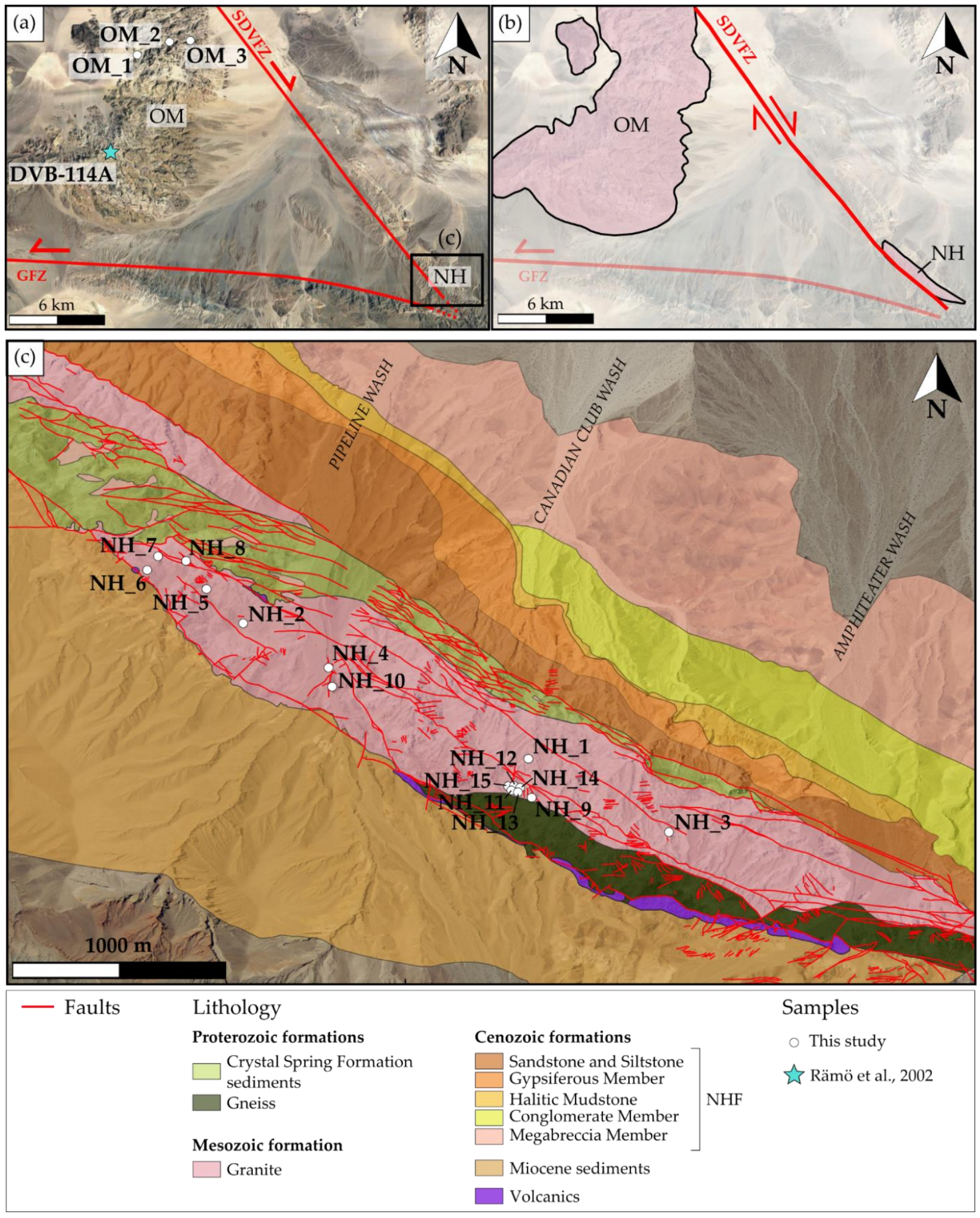

Figure 2. (a) Map presenting the structural setting of the southern part of the Death Valley region and the location of the Noble Hills range $(\mathrm{NH})$ and the location of samples in the Owlshead Mountains (OM) represented by the white dots. (b) A scheme showing the displacement of the NH granite from the OM along the SDVFZ described by [11]. (c) The geological map of the Noble Hills range, modified after [38,42]. The quaternary is not displayed but available on [38] map. In $(\mathbf{a}, \mathbf{b})$, samples location for this study are represented by the white dots; the blue star corresponds to a sample from [34]. NHF-Noble Hills Formation. 


\section{Material and Methods}

\subsection{Material and Sampling Strategy}

Fifteen samples from the $\mathrm{NH}$ granite and three samples from the OM granite (Figure 2) were collected in order to perform petrographical, mineralogical and geochemical characterizations. Hand specimens of centimetric size were collected in the two granite bodies $(\mathrm{OM}$ and $\mathrm{NH})$ in order to characterize their mineralogical changes.

The selection of those samples through the $\mathrm{NH}$ was done under one scope, consisting of target zones away from the faults in order to avoid their influence. In that case, the magmatic texture is preserved. These faults are striking mainly NW/SE (SDVFZ direction) ([12], this issue). In order to be more precise in the sample selection, this latter was also based on the degrees of microfracturing defined by [44], from microscopical observations. This scale was improved by attributing a value of fracture density, based on scanlines realized on thin section mosaics, for each degree of microfracturing, which is described in the Methods section.

All the samples are georeferenced for database supply as well as located precisely (Figure 2). The OM being considered as the same batholith as the NH granite [11], samples were collected in an area unaffected by the SDVFZ activity in order to have a reference protolith of the studied area. Thin sections as well as powders were prepared to perform the following analyses.

\subsection{Methods}

\subsubsection{Microscopic Observations}

A petrographical study performed on covered and polished thin-sections of 15 samples from the NH and two samples from the OM (OM_1 and OM_3), was realized at Institut Polytechnique UniLaSalle in Beauvais, using a Leica DM4500-P optical microscope equipped with a Leica DFC450C camera. Images were acquired thanks to the software Leica Application Suite (LAS) v4.11.0. The system is also equipped with a multistep acquisition program to perform thin section mosaics. It consists in the acquisition of several photos that follow each other in order to scan the whole thin section. At the end, the pictures are merged to obtain the mosaic. All the mineral abbreviations used in this paper refer to mineral symbols defined by [45]. The degree of mineral transformation into secondary minerals was defined based on optical observations.

\subsubsection{Fractures Density}

The studied samples were selected away from fracture zones, but also according to a certain degree of microfracturing based on the scale defined by [44]. For this study, fractures density values were calculated for each degree of microfracturing by using thin section mosaics. For each mosaic, two scanlines [46,47] perpendicular to the main fractures were realized by digitalizing fractures along both lines. The $\mathrm{P}_{10}$ [46] has been calculated for each scanline. It consists in the number of fracture intersects per line length of scanline. The average was calculated to obtain a value of fracture density attributed to each thin section mosaic and corresponding to each microfracturing degree defined by [44]:

$\mathrm{F}_{\mathrm{d}} 0<1687$ fracs $/ \mathrm{m}$-no to very low microfracturing

$\mathrm{F}_{\mathrm{d}} 1=1687$ fracs $/ \mathrm{m}$-microfracturing of order less than the grain size

$\mathrm{F}_{\mathrm{d}} 2=2694 \mathrm{fracs} / \mathrm{m}$, with a multiplicator factor of 1.6 - microfracturing of grain size order with interconnections

$\mathrm{F}_{\mathrm{d}} 3=3549 \mathrm{fracs} / \mathrm{m}$, with a multiplicator factor of 1.3 -abundant microfracturing $\mathrm{F}_{\mathrm{d}} 4 \geq 5140 \mathrm{fracs} / \mathrm{m}$ ([12] this issue), with a multiplicator factor of 1.4 -very abundant microfracturing

Samples selected for this study have so a fracture density lower or equal to $\mathrm{F}_{\mathrm{d}} 2$.

\subsubsection{SEM-EDS}

Scanning Electron Microscope (Hitachi S-3400N SEM) equipped with a Thermo Ultradry Energy Dispersive X-ray Spectrometer (EDS) probe was used on two polished 
thin sections and one hand specimen at Institut Polytechnique UniLaSalle in Beauvais. It aimed at analyzing the microstructure characteristics and to perform qualitative and semi-quantitative chemical analyses of various selected mineral phases.

A NORAN-type correction (@Thermo Fisher Scientific, Waltham, MA, USA) procedure was used for all data and all $\mathrm{Fe}$ was assumed to be ferrous for simplification. Polished thin sections were analyzed using a $50 \mu \mathrm{A}$ beam current, an accelerating voltage of $20 \mathrm{kV}$ and an acquisition time of $30 \mathrm{~s}$.

\subsubsection{X-ray Diffraction (XRD)}

Experimental Conditions

XRD analyses were performed at Institut UniLaSalle Beauvais on the 15 samples from the NH and one sample from the OM (OM_2) using a D8-Advance Bruker-AXS (Siemens, Munich, Germany) diffractometer with a Ni-filtered $\mathrm{CuK} \alpha$ radiation at $40 \mathrm{kV}$ and $40 \mathrm{~mA}$, a primary soller slit of $2.5^{\circ}$, divergence slit of $0.6 \mathrm{~mm}$ and a secondary soller slit of $2.5^{\circ}$, with a detector slit of $0.1 \mathrm{~mm}$ and an antiscattering slit of $0.6 \mathrm{~mm}$. Samples were crushed with an agate pestle and mortar. Quantitative phase analysis based on Reference Intensity Ratio values were performed on randomly oriented bulk rock powders with a step length of $0.5^{\circ}$ and a scan speed of $0.014^{\circ} / \mathrm{s}$ over the range $3^{\circ}-70^{\circ} 2 \theta$ for bulk rocks composition. The uncertainty is estimated to be around $5 \%$.

Determination of Illite Crystallinity and Kübler Index

XRD investigations were carried out on bulk rock powder specimens and clay fractions of 16 samples in order to identify and determine the relative abundance of mineral phases (semi-quantitative, around 3-5\%) observed upstream under the optical microscope and the SEM. Clay mineral separation was conducted using techniques described by [48], following the recommendations of [49], and according to the standard techniques suggested by [50]. It consists into the collection of the $<2 \mu \mathrm{m}$ and $2-6 \mu \mathrm{m}$ fractions from the sample powders put in suspension into water in decantation tubes. Oriented slides were then prepared by pipetting suspension onto glass slides $\left(5 \mathrm{mg} / \mathrm{cm}^{2}\right)$ and air-drying. XRD measurements were then performed at air dried, solvated with ethylene glycol, and after heating $\left(550^{\circ} \mathrm{C}\right)$ conditions with a step length of $0.5^{\circ}$ and a speed of $0.01^{\circ} / \mathrm{s}$ per step over the range $3^{\circ}-35^{\circ} 2 \theta$. The clay minerals identification, which is based on d-values and the relative intensity of their $00 l$ peak reflections, was undertaken referring to [51,52]. The illite "crystallinity" (IC), defined as the full width at half maximum (FWHM) of the $10 \AA$ (001) peak of illite, was calculated using the software DIFFRAC EVA v 4.2 (by @Bruker AXS, Billerica, MA, USA). The obtained values were standardized using the crystallinity index-standard (CIS) samples of [53] in order to calculate the Kübler Index (KI). The KI values of raw data expressed in $\Delta^{\circ} 2 \theta$, were measured into three slots, corresponding to different campaigns, inducing the three following standardizations:

$$
\begin{aligned}
& \mathrm{KI}_{(\mathrm{ULS} 1)}=1.6987 \times \mathrm{IC}_{\text {measured }}-0.0842\left(\mathrm{R}^{2}=0.9724\right) \\
& \mathrm{KI}_{(\mathrm{ULS} 2)}=1.5501 \times \mathrm{IC}_{\text {measured }}-0.0512\left(\mathrm{R}^{2}=0.9944\right) \\
& \mathrm{KI}_{(\mathrm{ULS} 3)}=1.5337 \times \mathrm{IC}_{\text {measured }}-0.0498\left(\mathrm{R}^{2}=0.9975\right)
\end{aligned}
$$

KI was used to define the limits of metamorphic zones [54], following the recommendations for Kübler-Index calibration of [50] and the CIS-KI transformation formalism of [55]. In siliciclastic rocks, the transitions from non-metamorphic to low-grade (referring to the term greenschist facies [56]) and from the very low-grade (chlorite zone [57]) to low-grade metamorphic zone (biotite zone [58]) take place through three zones defined by [13]: the diagenetic zone, the anchizone and the epizone. The zone boundary values are presented in Table 1. The smallest FWHM able to be measured by our diffractometer (limit detection) is $0.08 \Delta^{\circ} 2 \theta$. 
Table 1. Metamorphic zone boundaries [59] for Kübler Index (KI) values [55] and temperatures [60].

\begin{tabular}{ccc}
\hline Metamorphic Zone & KI $\left(\boldsymbol{\Delta}^{\circ} \mathbf{2 \theta}\right)$ & Temperature $\left({ }^{\circ} \mathbf{C}\right)$ \\
\hline Low Diagenesis & $>1$ & $\sim 100$ \\
High Diagenesis & $0.42-1$ & $\sim 200$ \\
Low Anchizone & $0.30-0.42$ & \\
High Anchizone & $0.25-0.30$ & $\sim 300$ \\
Epizone & $<0.25$ & \\
\hline
\end{tabular}

\subsubsection{ICP-MS-ICP-AES}

The analyses of major, trace and rare earth elements were completed on five selected samples from the NH (NH_1, NH_2, NH_3, NH_4 and NH_12) and one from the OM (OM_3) by Bureau Veritas Minerals (Vancouver, Canada) using ICP-ES and ICP-MS.

Samples were crushed and mixed with $\mathrm{LiBO}_{2} / \mathrm{LiB}_{4} \mathrm{O}_{7}$ flux. Crucibles were fused in a furnace at $980{ }^{\circ} \mathrm{C}$. Then, the cooled bead was dissolved in ACS grade nitric acid and analyzed by ICP-AES and/or ICP-MS. Loss on ignition (LOI) was determined by igniting the samples split then measuring the weight loss.

\subsubsection{Manocalcimetry}

Calcite contents were determined using an OFITE 152-95 manocalcimeter. The analyses were performed on 15 samples from the $\mathrm{NH}$ and one sample from the OM at CY Cergy Paris University in the Geosciences and Environment Cergy (GEC) laboratory. It provides an indication of the total carbonate content in a sample and allows to assess the influence of calcite on permeability of the fluid pathways. This is achieved by measuring the rate of response of $10 \%$ hydrochloric acid on the samples. Calcimetry has also proved to be an efficient, easy and low-cost method to better understand the hydrothermal sealing of a reservoir [61].

Manocalcimetry consists into the measurements of $\mathrm{CO}_{2}$ partial pressure when calcite is dissolved by $\mathrm{HCl}$. The reaction that occurs is:

$$
\mathrm{CaCO}_{3(\mathrm{~s})}+2 \mathrm{HCl}_{(\mathrm{l})} \rightleftarrows \mathrm{CO}_{2(\mathrm{~g})}+\mathrm{H}_{2} \mathrm{O}_{(\mathrm{l})}+\mathrm{CaCl}_{2}
$$

The calcimeter, composed of a glass flask and a high precision manometer calibrated with pure calcite reduced into fine powder. This allows us to determine the calcimeter coefficient. Variation of temperature and pressure can cause uncertainty on measurements, which was considered to obtain high quality results with a precision around $0.5 \mathrm{wt} . \%$.

Prior to measurements, sample preparation was done according to [61]. The samples were reduced into powder in an agate mortar and put in the oven at $60{ }^{\circ} \mathrm{C}$ for $24 \mathrm{~h}$. Then, $1.000 \mathrm{~g}$ of each sample was weighed and put in a sample holder, itself put in the calcimeter with a little glass filled with $\mathrm{HCl}$. The amount of $\mathrm{HCl}$ is in excess in order to dissolve all the calcite present in the sample. The maximum value reached during the measurement was read on the manometer and the $\mathrm{CaCO}_{3}$ percentage was determined as follows:

$$
\% \mathrm{CaCO}_{3}=(\text { Measured value } \times 100) / \text { Calcimeter coefficient }
$$

Two replicates were performed for each sample in order to check the reproducibility of the results, which is considered as good when the difference between the two results is lower than $0.5 \mathrm{wt} . \%$, corresponding to the precision interval mentioned above.

\subsubsection{Ethanol Saturation Porosimetry}

The estimation of available volume for fluid storage is fundamental and can be quantified by porosity measurements [62]. The connected porosity was measured on 6 samples from the $\mathrm{NH}$ and one from the OM by the triple weighing method [63] defined by the RILEM standard (test $n^{\circ} I .1,1978$ ). It consists in the saturation of the samples after 
vacuum degassing. The measurements were carried out at CY Cergy Paris University in the Laboratory of Mechanics and Materials for Civil Engineering (L2MGC).

In this study, ethanol has been chosen instead of water, as used in classical methods, in order to avoid possible clay swelling [64], which could lead to the destruction of the sample and biased results. Even though ethanol $(0.469 \mathrm{~nm})$ is a molecule larger than that of water $(0.343 \mathrm{~nm})$, the pore volume is not estimated to be under-evaluated, as the pore size is much larger than that of ethanol molecules. The samples were first oven-dried at approximately $40^{\circ} \mathrm{C}$ until obtaining a constant weight (W1). Samples were then soaked by capillary action with ethanol after staying for $12 \mathrm{~h}$ under a vaccum. When the samples were completely immersed, the vacuum was stopped and the samples left in the ethanol for $24 \mathrm{~h}$. Finally, they were weighted twice: (1) weighing of saturated samples, W2; and (2) weighing of samples under "ethanostatic" conditions (suspended into ethanol under the balance), W3. The connected porosity $\phi$ is then calculated:

$$
\phi(\%)=(W 2-W 1 / W 2-W 3) \times 100
$$

\section{Results}

\subsection{Petrographic Description}

\subsubsection{The Owlshead Granite}

Samples of the OM granite appear rather fresh, meaning that primary minerals seem not transformed into secondary ones and present no sign of deformation. They show a light grey/whitish and yellowish granite (Figure $3 a)$ with equant medium-size grains $(0.1-1 \mathrm{~cm})$. Primary assemblage is composed of plagioclase, quartz, K-feldspar and biotite. Biotite is generally surrounded by a yellowish oxide halo, showing its incipient alteration.

OM granite microscopic observations (Figure $3 b, c$, Table 2) confirm the freshness of the rock as well as the very low to absent microfracturing. Figure $3 \mathrm{~b}$ shows a microfracturing around $\mathrm{F}_{\mathrm{d}} 1$ (Table 2). Most of the fractures are open and a few of them are filled by calcite. Calcite is also present at the grain boundaries (Figure $4 a, b$ ).

Regarding mineralogical composition, plagioclase ( $35 \%$, modal composition) occurs subautomorphous crystals, up to $5 \mathrm{~mm}$, of oligoclase composition with an oscillatory zonation [65] (Figure 3b). Quartz (35\%) forms up to $2 \mathrm{~cm}$ polycrystalline clusters of anhedral crystals which range up to $1 \mathrm{~cm}$ and present a slight rolling extinction. K-feldspar $(25 \%)$ occurs as centimetric subautomorphous crystals of microcline and orthoclase with a Carlsbad twin, rich in perthites (albite vein or braid/patch shape [65] (Figure 4a,b). Kfeldspar crystals can contain plagioclase and biotite inclusions. Biotite (5\%) of around 2 $\mathrm{mm}$ in length is euhedral. Primary opaque minerals $(<1 \%)$ are also found in this granite.

The core of plagioclase is slightly transformed into K-white mica (Figures $3 \mathrm{c}$ and $4 \mathrm{c}, \mathrm{d}$ ). They will be represented as Wm. Quartz and K-feldspar are not affected by the alteration and are only little undeformed as seen on quartz showing undulatory extinction (Figure 4a). Biotite can be slightly altered. Few epidotes are present nearby the biotite (Figure 4e,f).

Microscopic observations of samples OM_3 and OM_1 are consistent with whole rock XRD analyses performed on the sample OM_2 from the OM granite. The three samples have a similar mineralogical composition and are grouped together in Table 2. 


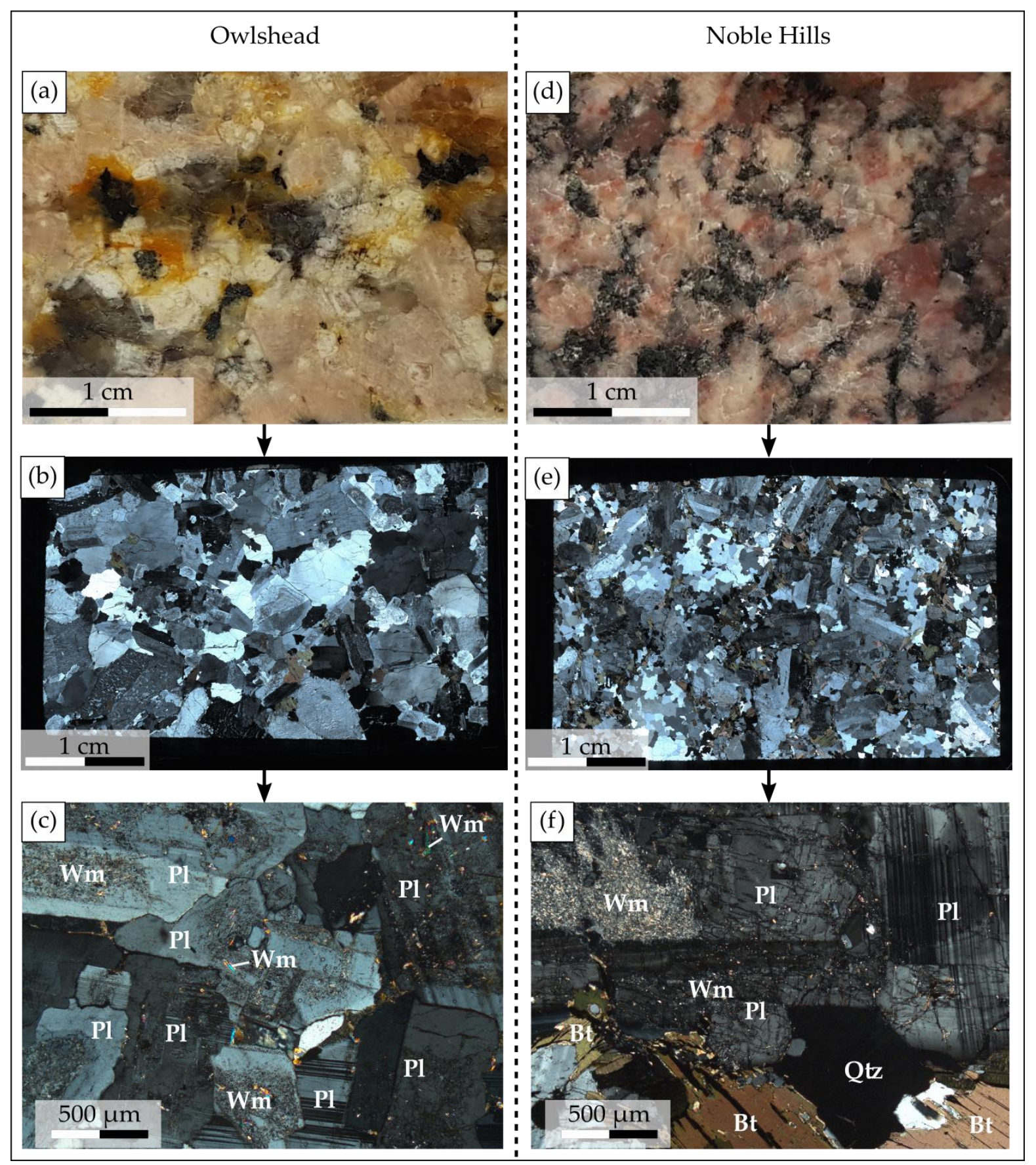

Figure 3. Macroscale to microscale photographs illustrating $(\mathbf{a}-\mathbf{c})$ the Owlshead and $(\mathbf{d}-\mathbf{f})$ the Noble Hills granites. (a,d) Hand specimens for each granite showing their different aspects. $(\mathbf{b}, \mathbf{e})$ Thin section mosaics realized for each granite under optical microscope in polarized-analyzed light and showing the difference in terms of grain size and microfracturing. $(\mathbf{c}, \mathbf{f})$ Thin sections zooms of each granite mosaic in polarized-analyzed light showing the difference in terms of alteration degree. Abbreviations (except for "Wm") after [45]: Bt—Biotite, Kfs-K-feldspar, Wm-K-white mica, Pl—Plagioclase, Qtz-Quartz. 


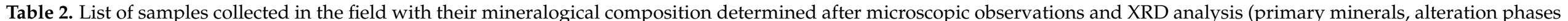

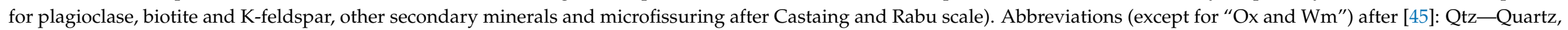

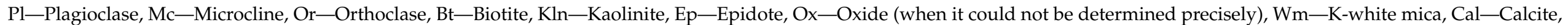
Dol—Dolomite, Hem-Hematite, Gp—Gypsum, Fd—Fracture density.

\begin{tabular}{|c|c|c|c|c|c|c|c|c|c|}
\hline \multirow[t]{3}{*}{ Sample ID } & \multirow[t]{3}{*}{ Primary Minerals } & \multicolumn{6}{|c|}{ Major Secondary Phases Within } & \multirow[t]{3}{*}{ Other Secondary Minerals } & \multirow[t]{3}{*}{ Microfracturing } \\
\hline & & \multicolumn{3}{|c|}{ Pl } & \multicolumn{2}{|c|}{ Bt } & \multirow{2}{*}{$\begin{array}{l}\text { Kfs } \\
\mathrm{Wm}\end{array}$} & & \\
\hline & & Wm & Kln & Cal & Wm & Ox & & & \\
\hline OM_1_2_3 & Qtz, Pl, Mc, Or, Bt, Ox & $\sqrt{ }$ & & & & & & $\mathrm{Ep}, \mathrm{Ox}, \mathrm{Wm}, \mathrm{Cal}$ & Fd1 \\
\hline NH_1 & Qtz, Pl, Mc, Or, Bt, Ox & $\sqrt{ }$ & $\sqrt{ }$ & & $\sqrt{ }$ & $\sqrt{ }$ & & Cal, Dol, Wm & $\mathrm{Fd} 1$ \\
\hline NH_2 & Qtz, Pl, Or, Bt, Ox & $\sqrt{ }$ & $\sqrt{ }$ & & & $\sqrt{ }$ & & Dol, Wm & $\mathrm{Fd} 1$ \\
\hline NH_3 & Qtz, Pl, Or, Bt, Ox & $\sqrt{ }$ & $\sqrt{ }$ & & $\sqrt{ }$ & $\sqrt{ }$ & $\sqrt{ }$ & Cal, Dol, Wm & Fd1-2 \\
\hline NH_4 & Qtz, Pl, Or, Bt, Ox & $\sqrt{ }$ & $\sqrt{ }$ & $\sqrt{ }$ & $\sqrt{ }$ & $\sqrt{ }$ & & Cal, Hem & Fd0-1 \\
\hline NH_5 & Qtz, Pl, Or, Bt, Ox & $\sqrt{ }$ & $\sqrt{ }$ & & & $\sqrt{ }$ & & Hem, Wm & Fd0-1 \\
\hline NH_7 & Qtz, Pl, Or, Bt, Ox & $\sqrt{ }$ & $\sqrt{ }$ & & $\sqrt{ }$ & $\sqrt{ }$ & & Cal, Ox, Wm & Fd1 \\
\hline NH_8 & Qtz, Pl, Or, Bt, Ox & $\sqrt{ }$ & $\sqrt{ }$ & $\sqrt{ }$ & $\sqrt{ }$ & $\sqrt{ }$ & & Cal, Ox, Wm & Fd1-2 \\
\hline NH_9 & Qtz, Pl, Or, Bt, Ox & $\sqrt{ }$ & $\sqrt{ }$ & & & & & Cal, Ox, Wm & Fd0-1 \\
\hline NH_10 & Qtz, Pl, Or, Bt, Ox & $\sqrt{ }$ & $\sqrt{ }$ & $\sqrt{ }$ & $\sqrt{ }$ & $\sqrt{ }$ & & Cal, Hem, Wm, Ep & $\mathrm{Fd} 2$ \\
\hline NH_11 & Qtz, Pl, Or, Bt, Ox & $\sqrt{ }$ & $\sqrt{ }$ & $\sqrt{ }$ & $\sqrt{ }$ & $\sqrt{ }$ & & Cal, Hem, Wm & Fd1-2 \\
\hline NH_12 & Qtz, Pl, Mc, Or, Bt, Ox & $\sqrt{ }$ & $\sqrt{ }$ & $\sqrt{ }$ & $\sqrt{ }$ & $\sqrt{ }$ & & Cal, Hem, Gp, Wm & Fd0-1 \\
\hline NH_13 & Qtz, Pl, Mc, Or, Bt, Ox & $\sqrt{ }$ & $\sqrt{ }$ & $\sqrt{ }$ & $\sqrt{ }$ & $\sqrt{ }$ & & Cal, Hem, Gp, Wm & Fd0-1 \\
\hline NH_14 & $\mathrm{Qtz}, \mathrm{Pl}, \mathrm{Mc}, \mathrm{Or}, \mathrm{Bt}, \mathrm{Ox}$ & $\sqrt{ }$ & $\sqrt{ }$ & $\sqrt{ }$ & $\sqrt{ }$ & $\sqrt{ }$ & & Cal, Hem, Gp, Wm & $\mathrm{Fd} 0-1$ \\
\hline NH_15 & Qtz, Pl, Or, Bt, Ox & $\sqrt{ }$ & $\sqrt{ }$ & & $\sqrt{ }$ & $\sqrt{ }$ & & Cal, Mag, Wm & Fd1-2 \\
\hline
\end{tabular}



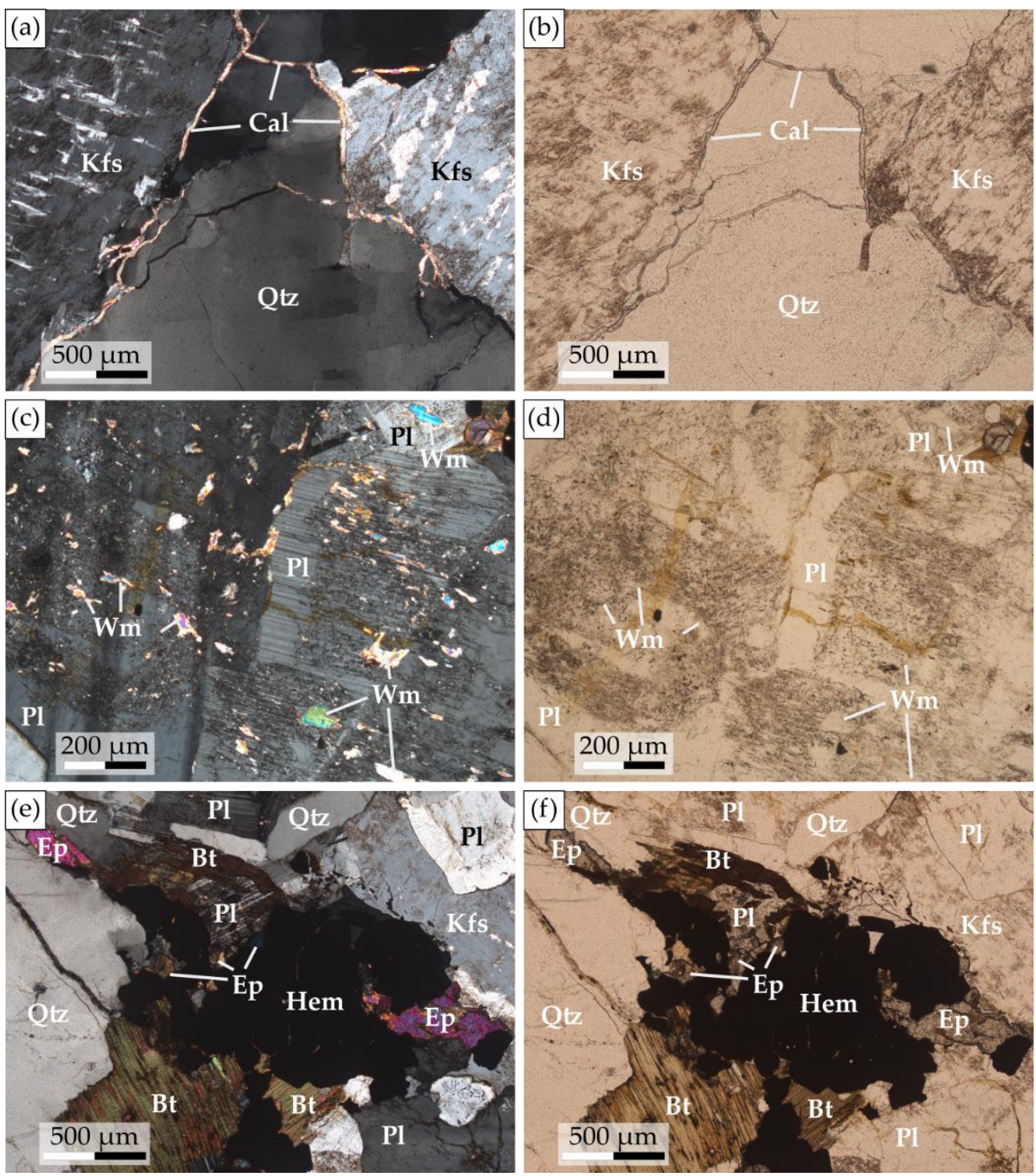

Figure 4. Photomicrographs of the Owlshead granite in polarized-analyzed and polarized-nonanalyzed light showing $(\mathbf{a}, \mathbf{b})$ perthitic and unaltered orthoclase, unaltered quartz presenting a slight undulatory extinction and calcite veinlets at grain boundaries. (c,d) Plagioclase alteration with the formation of K-white mica. (e,f) Incipient biotite alteration associated to hematite and epidote formation. Abbreviations (except for "Wm") after [45]: Bt-Biotite, Cal-Calcite, Ep-Epidote, Hem-Hematite, Kfs-K-feldspar, Wm-K-white mica, Pl—Plagioclase, Qtz-Quartz.

\subsubsection{The Noble Hills Granite}

Far from the major faults, the NH granite appears, as a whole, microfractured and altered. with preserved "fresh" zones. The collected hand specimens (Figure 2b) are equant to slightly porphyritic and display a pinkish color (Figure 3d) or a whitish color for the samples with evidences of alteration. Primary assemblage, as for the OM granite, is made of plagioclase, quartz, K-feldspar and biotite.

At the microscale, the degree of microfracturing ranges from $\mathrm{F}_{\mathrm{d}} 0-1$ to $\mathrm{F}_{\mathrm{d}} 2$ (Table 2). As for the OM granite, the microfractures can be opened or filled by carbonates. As regards mineralogical composition, plagioclase ( $\sim 35 \%$, oligoclase in composition) occurs as sub-anhedral to euhedral crystals (up to $5 \mathrm{~mm}$ in length) showing growth zonation (see Figure $3 \mathrm{f}$ and [65]). Quartz ( $30 \%)$ forms polycrystalline euhedral clusters of around $1 \mathrm{~cm}$ in size made of 3-mm-wide crystals with sometimes a slight undulatory extinction linked to low deformation. K-feldspar $(\sim 25 \%)$ is made of sub-anhedral to euhedral orthoclase 
(up to $1 \mathrm{~cm}$ in length) with vein shaped perthites [65]. Microcline is only present in the samples NH_12 and NH_14, in the southern part of the range (Figure 2 and Table 2). Some K-feldspar crystals contain inclusions of plagioclase or/and biotite. Depending on the samples, the amount of plagioclase can be equivalent to that of K-feldspar ( $30 \%$ each), but most of the time, plagioclase dominate. Myrmekite can be observed at the interface between plagioclase and K-feldspar. Biotite $(\sim 10 \%)$ appears euhedral with crystals $\sim 2 \mathrm{~mm}$ in length. Accessory minerals $(<1 \%)$ as apatite are also observed. More rarely, primary muscovite, as well as primary opaque minerals (oxides) are observed in the granite. A comparison between the $\mathrm{NH}$ and the OM granites highlights a grain size difference. Quartz and Kfeldspar crystals are smaller in the $\mathrm{NH}$ granite (up to $3 \mathrm{~mm}$ and $1 \mathrm{~cm}$ respectively, Figure 3e) than in the OM granite (up to $1 \mathrm{~cm}$ and centimetric crystals respectively, Figure $3 \mathrm{~b}$ ).

Primary minerals, function of their sensitivity to alteration [65], recrystallized into secondary minerals which are shown in Table 2. This is related to differences into chemical properties [66]. In the plagioclase, which is the most altered mineral (Figure 5), recrystallization propagate from the core of the crystal to the more albitic rim (Figure 5a) [67]. When alteration is intense, plagioclase is entirely replaced by newly formed minerals leaving only the pseudomorph of the plagioclase to subsist (Figure $5 \mathrm{~d}$ ). The newly formed minerals are the following:

- Illite is the most frequent and occurs as tiny flakes or needles 0.5 to $8 \mu \mathrm{m}$ width and up to $40 \mu \mathrm{m}$ long [68] (Figure 5b,c).

- Kaolinite is present as fan shape (Figure $5 \mathrm{e}, \mathrm{f}$ ) of $25 \mu \mathrm{m}$ to $40 \mu \mathrm{m}$ in diameter. Under SEM (Figure 5f), well crystallized kaolinite presents a porous structure which can contribute to the porosity of the rock. It is only present in the NH granite (Table 3) indicating that the $\mathrm{NH}$ granite has undergone a different alteration from that of the OM granite.

- Calcite, which occurs as small spots, is mainly associated with kaolinite (Figure 5d,e). It crystallizes in the porosity created by plagioclase dissolution.

Illite and kaolinite can be present together in the same sample (Figure 5d).

The K-feldspar remains always unaffected (Figure $5 \mathrm{~d}$ ), but when the alteration is relatively pronounced, perthites can be altered as well as the mineral inclusions like in sample NH_3 Table 2). Biotite is progressively replaced by K-white mica (illite) as compared to the biotite in the OM granite (Table 2). K-white mica crystallizes along the cleavages and can be associated to the crystallization of oxides, as hematite, also along the cleavages (Figure 6).

Table 3. List of samples with their respective clay minerals composition, FWHM and Kübler Index (KI) for the fractions $<2 \mu \mathrm{m}$ and 2-6 $\mu \mathrm{m}$. Abbreviations (except for "Cor") after [45]: Ill—Illite, Kln—Kaolinite, Cor-Corrensite, I/SIllite/Smectite, Vrm—Dioctahedral Vermiculite, Bt—Biotite, Mnt-Montmorillonite, AD—Air-dried.

\begin{tabular}{|c|c|c|c|c|c|c|c|c|c|c|c|c|c|c|c|}
\hline \multirow{2}{*}{ Sample ID } & \multicolumn{5}{|c|}{$<2 \mu \mathrm{m}$} & \multicolumn{6}{|c|}{$2-6 \mu \mathrm{m}$} & \multicolumn{2}{|c|}{$<2 \mu \mathrm{m}$ (AD) } & \multicolumn{2}{|c|}{$2-6 \mu \mathrm{m}(\mathrm{AD})$} \\
\hline & Ill & Kln & Cor & I/S & Bt & Ill & $K \ln$ & Cor & $\mathrm{I} / \mathrm{S}$ & Mnt & Bt & FWHM & KI & FWHM & KI \\
\hline OM_2 & \multicolumn{5}{|c|}{ no material } & - & & & & + & & & & 0.18 & 0.22 \\
\hline NH_1 & + & - & & & ++ & - & + & & & & ++ & 0.48 & 0.69 & 0.34 & 0.46 \\
\hline NH_2 & -- & - & & & ++ & -- & - & & & & ++ & 0.31 & 0.43 & 0.32 & 0.44 \\
\hline NH_3 & + & + & ++ & & & + & + & ++ & & & & 0.63 & 0.92 & 0.59 & 0.87 \\
\hline NH_4 & ++ & + & - & & & ++ & + & - & & & & 0.81 & 1.29 & 0.73 & 1.16 \\
\hline NH_5 & + & - & - & & & - & - & - & & & + & 0.69 & 1.09 & 0.37 & 0.55 \\
\hline NH_6 & + & ++ & & - & & + & ++ & & - & & & 1.37 & 2.25 & 1.15 & 1.87 \\
\hline NH_7 & + & + & & - & & + & + & & - & & + & 1.01 & 1.63 & 0.71 & 1.13 \\
\hline NH_8 & + & + & + & & & + & ++ & + & & & & 1.10 & 1.79 & 1.18 & 1.93 \\
\hline NH_9 & + & + & ++ & & & + & + & ++ & & & & 0.85 & 1.36 & 0.56 & 0.87 \\
\hline NH_10 & + & - & & & ++ & + & - & & & & ++ & 0.46 & 0.65 & 0.51 & 0.73 \\
\hline NH_11 & ++ & - & + & & & ++ & + & + & & & & 0.67 & 1.05 & 0.62 & 0.97 \\
\hline NH_12 & ++ & + & & - & & ++ & + & & - & & & 0.57 & 0.89 & 0.46 & 0.69 \\
\hline NH_13 & + & - & + & & & + & - & + & & & & 0.46 & 0.69 & 0.38 & 0.56 \\
\hline NH_14 & + & -- & - & & + & + & -- & - & & & + & 0.59 & 0.92 & 0.44 & 0.66 \\
\hline NH_15 & + & - & + & & & + & - & - & & & & 0.69 & 1.08 & 0.50 & 0.77 \\
\hline
\end{tabular}



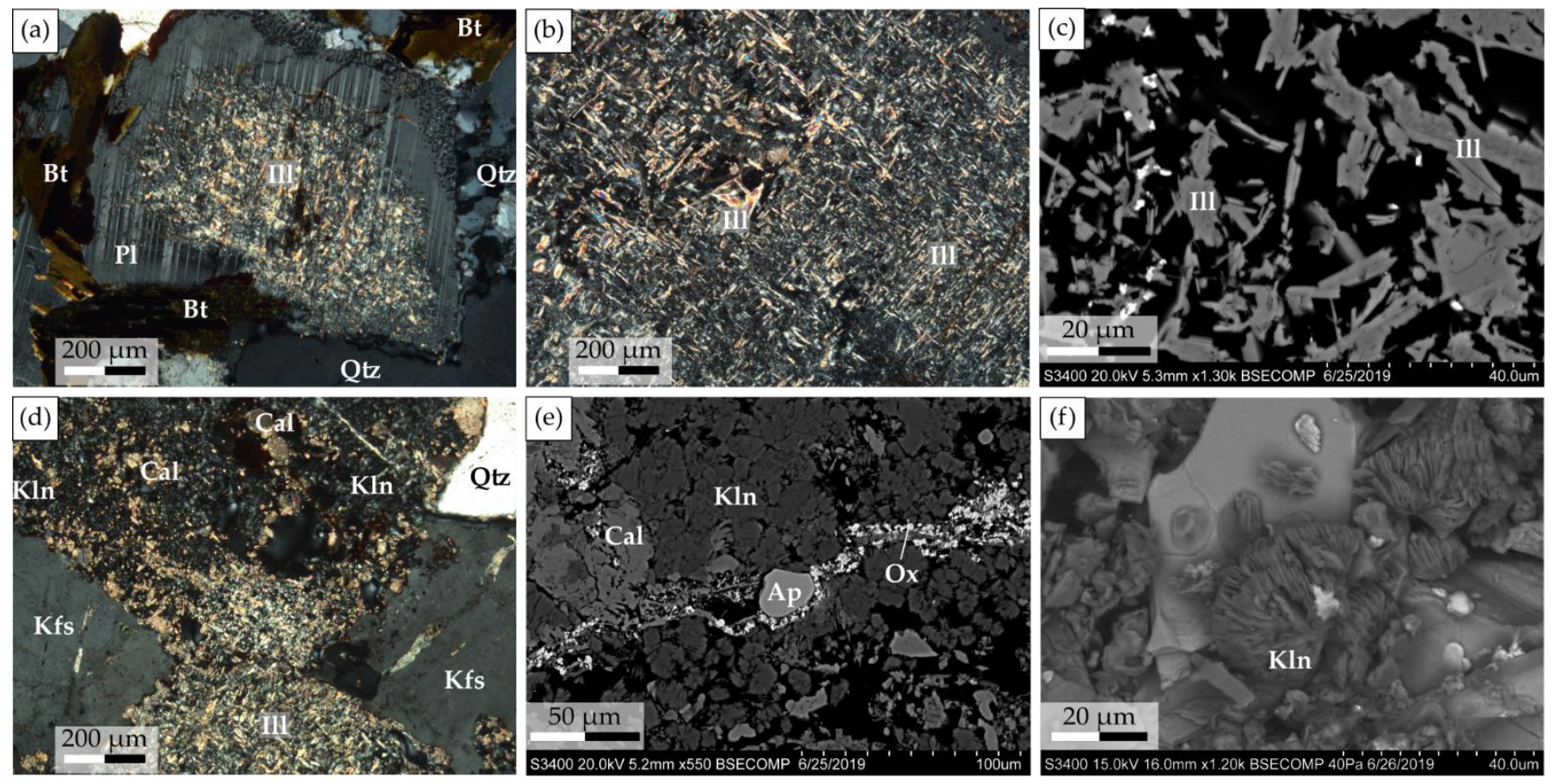

Figure 5. Photomicrographs showing the plagioclase transformation progress in the Noble Hills granite. (a) Progressive illitization of plagioclase initiating in the core of the mineral under optical microscope in polarized-analyzed light. (b) Needles shape illite replacing plagioclase in polarized-analyzed light under optical microscope. (c) Back-scattered electron image of needles/flakes shape illite replacing plagioclase. (d) Plagioclase completely replaced by illite, kaolinite and calcite and non-altered K-feldspar under optical microscope in polarized-analyzed light. (e) Back-scattered electron image showing a fan shape kaolinite, calcite and oxide veinlet. (f) Back-scattered electron image showing a magnified view of a single mineral of kaolinite under SEM. Abbreviations (except for "Ox") after [45]: Ap—Apatite, Bt—Biotite, Cal—Calcite, Ill—Illite, Kln—Kaolinite, Kfs—K-feldspar, Ox—Oxides, Pl—Plagioclase, Qtz—Quartz.
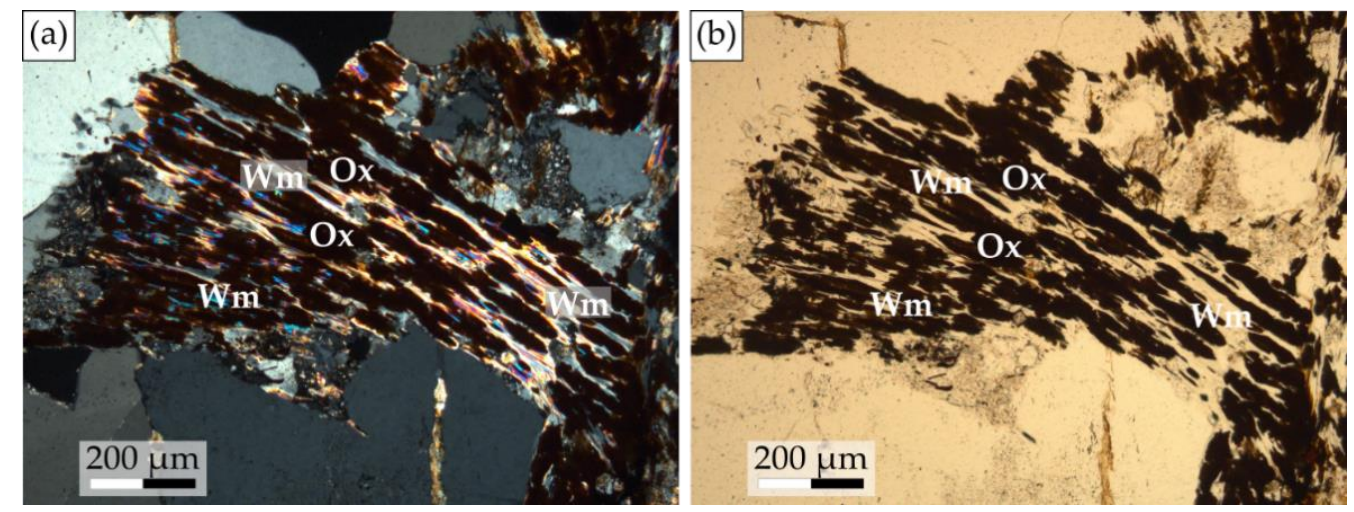

Figure 6. Photomicrographs showing a biotite completely altered and replaced by oxides and Kwhite mica (essentially illite) according to the cleavage planes (a) in polarized-analyzed light under optical microscope and (b) in polarized-analyzed light under optical microscope. Abbreviations (except for "Ox and Wm") after [45]: Bt—Biotite, Cal-Calcite, Kfs-K-feldspar, Wm-K-white mica, Ox-Oxides, Pl—Plagioclase, Qtz-Quartz.

All the samples are plotted in the Streckeisen ternary diagram (Figure 7) [68]. The $\mathrm{OM}$ and NH granites of this study are both defined as monzogranites. The OM sample analyzed by [34] (Figure 2a, blue star) shows a different composition (Figure 7, blue star). It is rather a monzonite, as defined by [34], than a monzogranite, as defined in this study. 


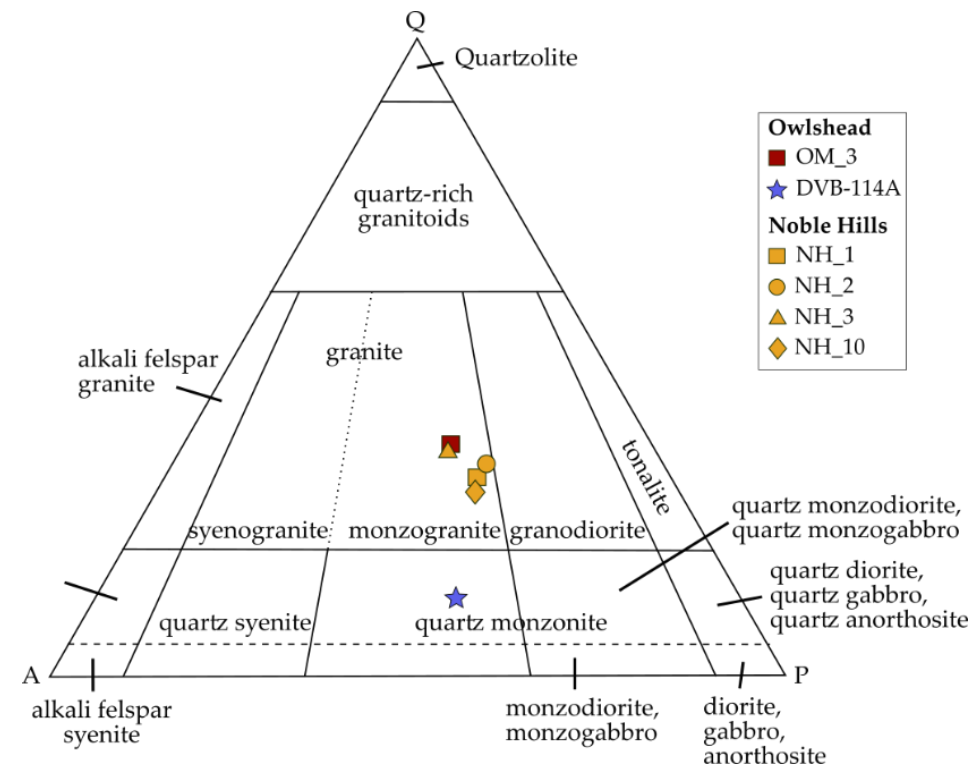

Figure 7. Normative composition of one sample from the OM and 4 samples from the NH in a QAP (Quartz-Alkali-feldspar-Plagioclase) ternary diagram [68].

\subsubsection{Clay Minerals Identification and Kübler INDEX}

Clay minerals from the $<2 \mu \mathrm{m}$ and $2-6 \mu \mathrm{m}$ fractions were separated. The clay composition of both fractions of each studied sample (OM and $\mathrm{NH})$ is given in Table 3, based on [51].

\section{Owlshead Mountains}

The OM sample clay analyses confirm the presence of illite observed under optical microscope. They also reveal the pattern of montmorillonite (Mnt) [51], a common smectite (Figure 8). Its very intense 001 peak allows the determination of its amount representing $15 \%$ of the clay fraction. This peak is characterized by a shift from $14.87 \AA$ (air-dried) to $16.90 \AA$ after glycol solvation and it collapses at $10.09 \AA$ after heating. After glycol solvation, new peaks appear at $5.61 \AA$ and $8.46 \AA$.

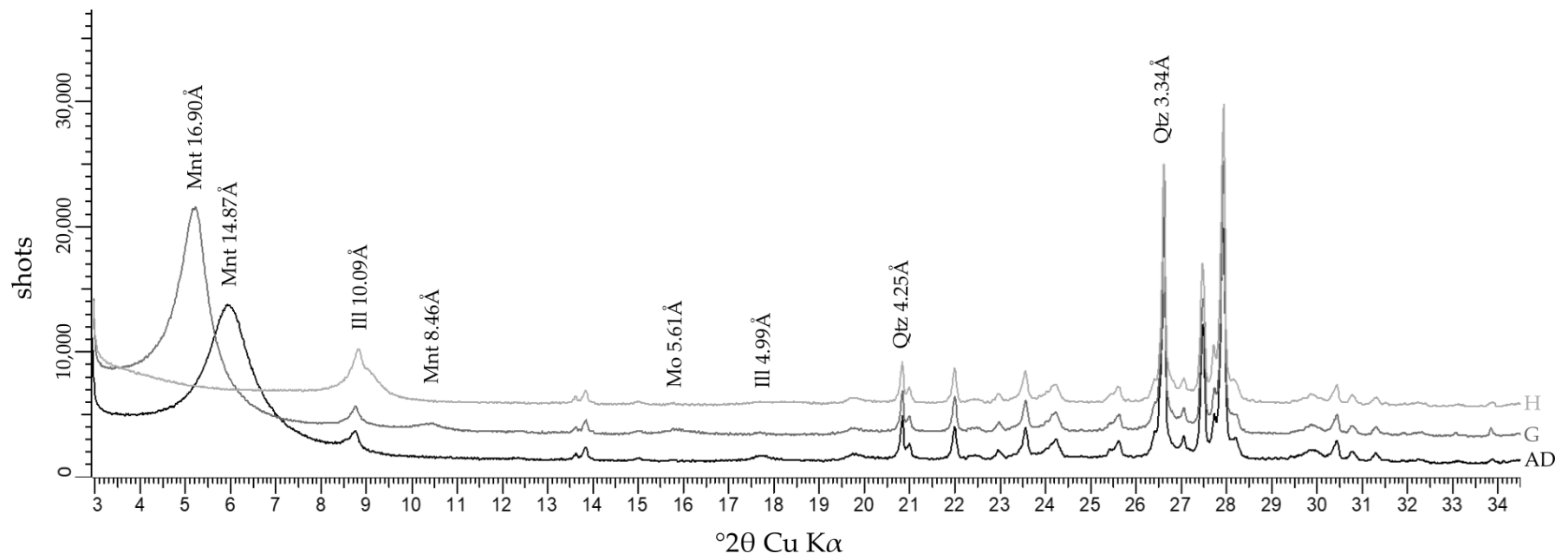

Figure 8. XRD result obtained for the clay fraction $<2 \mu \mathrm{m}$ in Air-Dried (AD), Glycolated (G) and Heated (H) of the samples in the OM granite and showing a montmorillonite (Mnt) pattern. 


\section{Noble Hills}

Two typical XRD patterns of clay minerals are identified in the NH samples for the $<2 \mu \mathrm{m}$ fraction (Figure 9):

- Corrensite, kaolinite and illite are identified in the first pattern, where corrensite is well known as the trioctahedral variety of regular 50:50 mixed-layer chlorite/smectite [69] (Figure 9a). It is characterized by (1) the peak at $13.60 \AA$ in air-dried conditions, shifting to $15.62 \AA$ after glycol solvation and collapses to $11.72 \AA$ after heating, and (2) new peaks at $7.78 \AA, 5.15 \AA$ and $3.44 \AA$ appear after glycol solvation and disappear after heating. The corrensite found in the NH granite is considered as a low charge corrensite after [51].

- Illite/smectite (I/S) mixed-layer, kaolinite and illite (Figure $9 \mathrm{~b}$ ) are identified in the second pattern, where I/S is illite-rich (R3), with more than $90 \%$ of illite and R representing the Reichweite parameter [70]. I/S is characterized by a large peak at $10.08 \AA$ in air-dried, becoming narrower when it collapses to $9.93 \AA$ after glycol solvation and by a peak at $5 \AA$ swelling after glycol solvation.
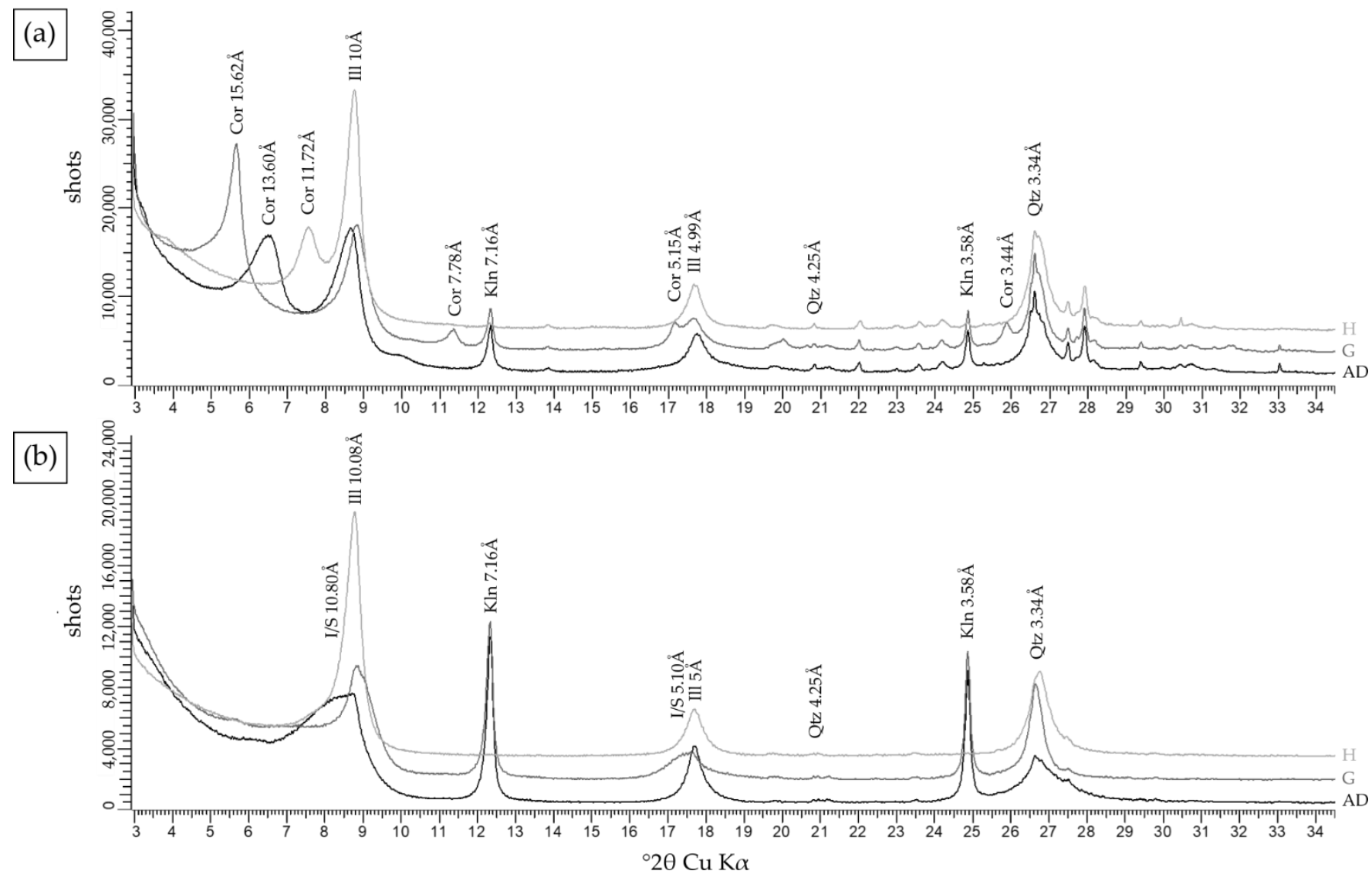

Figure 9. XRD patterns obtained for the clay fraction $<2 \mu \mathrm{m}$ in Air-Dried (AD), Glycolated (G) and Heated (H) for the $\mathrm{NH}$ granite and showing the clay composition of the samples in the NH granite: (a) corrensite (Cor), a chlorite/smectite mixed-layer, and (b) illite/smectite mixed-layer (I/S). Abbreviations (except for "Cor and I/S") after [45]: Bt—Biotite, Kln-Kaolinite, Qtz-Quartz, Ill-Illite.

In the NH KI values range from $2.25 \Delta^{\circ} 2 \theta$ to $0.43 \Delta^{\circ} 2 \theta$ for the $<2 \mu \mathrm{m}$ fraction and from $1.93 \Delta^{\circ} 2 \theta$ to $0.44 \Delta^{\circ} 2 \theta$ for the $2-6 \mu \mathrm{m}$ fraction (Table 3). The spatial distribution of the samples and the KI values are shown in Figure 10. A NW to SE decrease in KI values in the main granitic body is distinguishable in the $<2 \mu \mathrm{m}$ fraction (Figure 10a) and confirmed in the $2-6 \mu \mathrm{m}$ fraction (Figure 10b). 

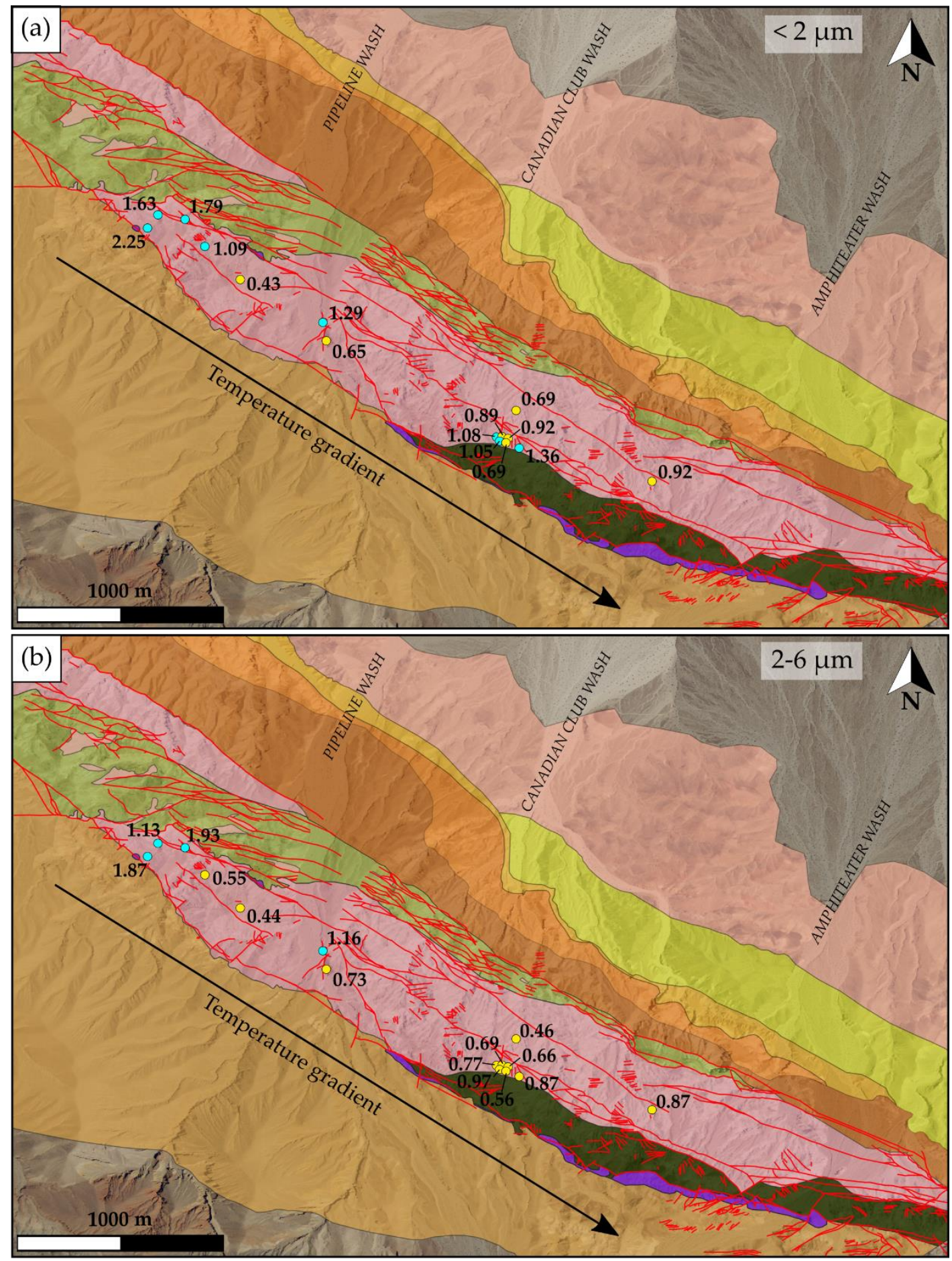

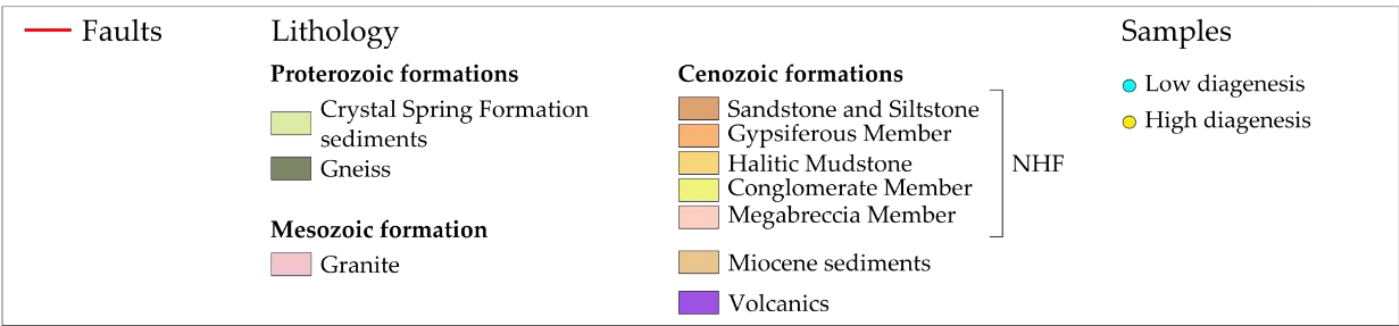

Figure 10. Geological map (see Figure 2b) representing the Kübler Index (KI) in air dried conditions of each sample and the corresponding metamorphic zone showed by the color of the dots for (a) the fraction $<2 \mu \mathrm{m}$ and (b) the fraction $2-6 \mu \mathrm{m}$. 


\subsection{Geochemical Analyses}

\subsubsection{Major Element Bulk Rock Chemistry}

Major element geochemistry (Table 4) allows classifying the granite samples in different diagrams (Figures 11 and 12).

Table 4. Major elements of the Owlshead and Noble Hills granites.

\begin{tabular}{cccccc}
\hline Sample ID & OM_3 & NH_10 & NH_1 & NH_2 & NH_3 \\
\hline $\mathrm{SiO}_{2}$ & 74.65 & 68.54 & 69.56 & 68.69 & 68.78 \\
$\mathrm{Al}_{2} \mathrm{O}_{3}$ & 12.90 & 15.36 & 14.93 & 14.53 & 14.99 \\
$\mathrm{Fe}_{2} \mathrm{O}_{3}$ & 1.83 & 3.02 & 2.83 & 4.29 & 2.95 \\
$\mathrm{MgO}$ & 0.31 & 0.57 & 0.56 & 1.15 & 0.78 \\
$\mathrm{CaO}$ & 1.09 & 2.62 & 2.20 & 2.50 & 1.99 \\
$\mathrm{Na}$ & 3.51 & 3.31 & 3.42 & 3.19 & 2.78 \\
$\mathrm{~K}_{2} \mathrm{O}$ & 4.43 & 4.31 & 4.10 & 3.60 & 4.22 \\
$\mathrm{TiO}_{2}$ & 0.20 & 0.29 & 0.26 & 0.46 & 0.28 \\
$\mathrm{P}_{2} \mathrm{O}$ & 0.07 & 0.14 & 0.13 & 0.20 & 0.14 \\
$\mathrm{MnO}$ & 0.08 & 0.09 & 0.08 & 0.12 & 0.08 \\
\hline
\end{tabular}
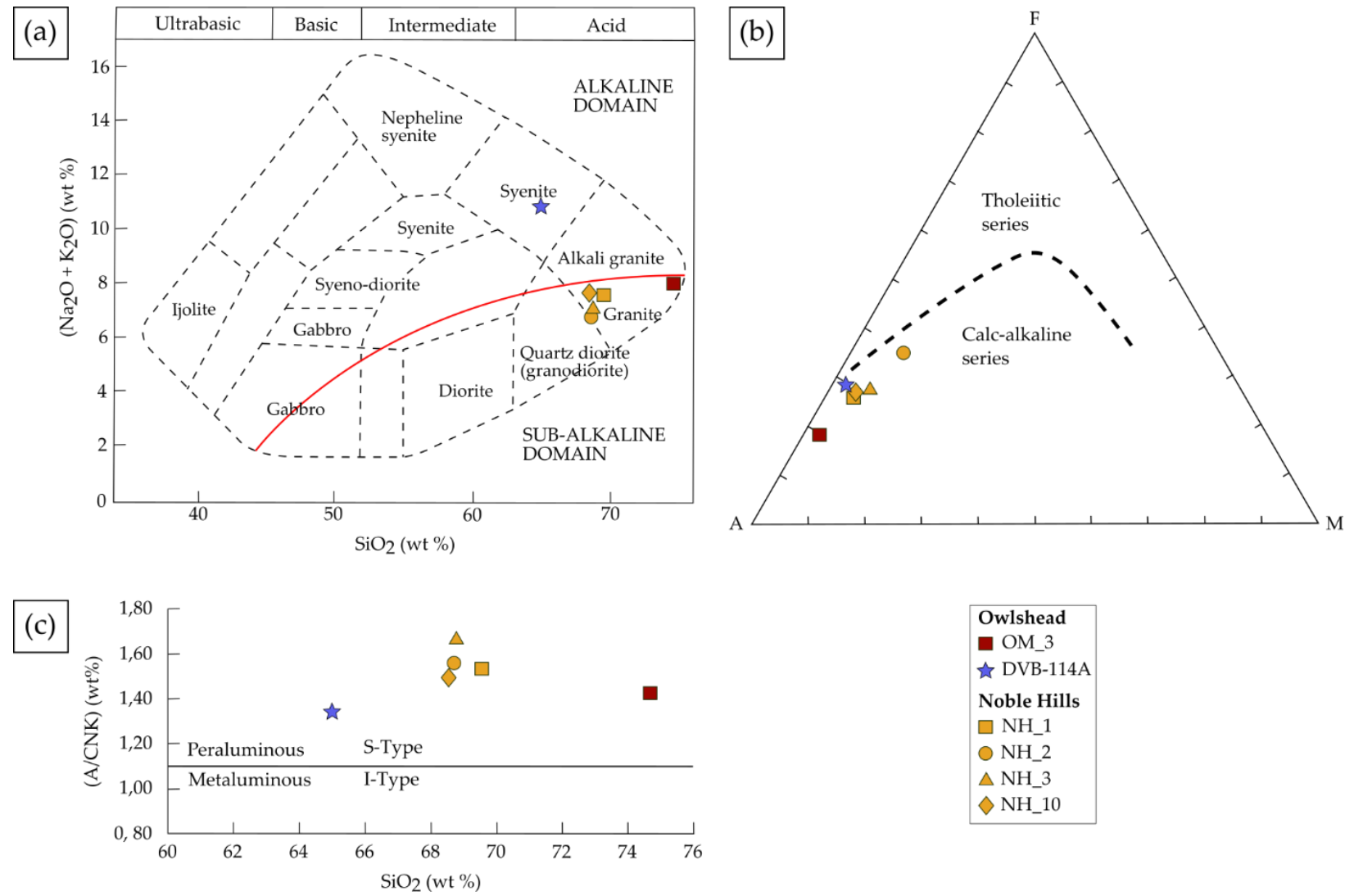

Figure 11. (a) Total alkali versus silica diagram ([71] adopted for plutonic rocks by [72]). (b) AFM ( $\left.\mathrm{Alkali}-\mathrm{Fe}_{2} \mathrm{O}_{3}-\mathrm{MgO}\right)$ classification diagram established by [73]. (c) $\mathrm{A} / \mathrm{CNK}\left(\mathrm{Al}_{2} \mathrm{O}_{3} /\left(\mathrm{CaO}+\mathrm{Na}_{2} \mathrm{O}+\mathrm{K}_{2} \mathrm{O}\right)\right)$ versus silica diagram. The blue star corresponds to a sample from the OM analyzed by [34].

In the $\mathrm{Na}_{2} \mathrm{O}+\mathrm{K}_{2} \mathrm{O}$ versus $\mathrm{SiO}_{2}$ classification (called TAS) diagram of [71], modified after [72] for plutonic rocks, all the samples plot in the sub-alkalic domain. They all have a granite composition close to the granodiorite zone (Figure 11a). However, the sample from [34] plots in the syenite field, while it plots in the monzonite field in the Streckeisen diagram (Figure 7). The AFM triangular plot classifies all the samples as calc-alkaline 
(Figure 11b). The silica content of the OM granite $74.65 \mathrm{wt} . \%$ is higher than that of the $\mathrm{NH}$ granite which ranges from 68.54 to 69.56 wt.\%. According to the $\mathrm{SiO}_{2}$ versus $\mathrm{A} / \mathrm{CNK}$ diagram (Figure 11c) [74], all the samples are peraluminous rocks, and are found rather far from the boundary with metaluminous S-type granites, with a A/CNK between 1.4 and $1.6 \mathrm{wt}$ \%. Harker diagrams complete the information by showing a high content of $\mathrm{K}_{2} \mathrm{O}$ ranging from 3.6 to $4.43 \mathrm{wt}$ \%, and plot the samples in the high-K calc-alkaline domain (Figure 12a) which limits where defined by [75]. However, the OM sample has a lower $\mathrm{Al}_{2} \mathrm{O}_{3}$ content (12.9 wt.\%) than the $\mathrm{NH}$ samples (14.53-15.36 wt.\%) forming a separate cluster (Figure 12b). Again, the sample from [45] (DVB-114A-blue star) shows a large difference in composition compared to OM_3.

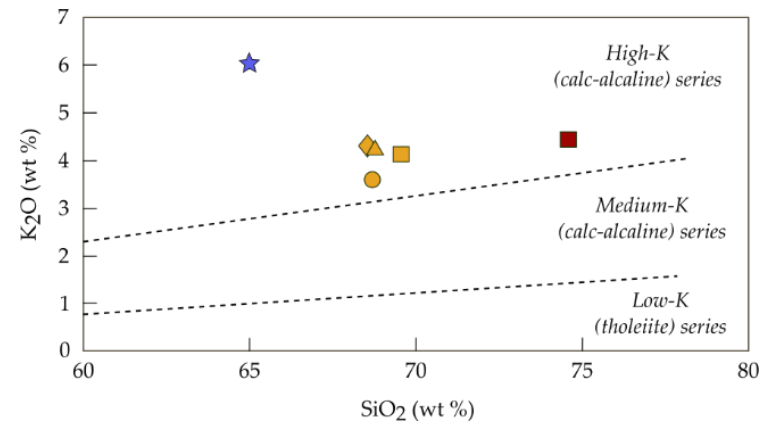

(a)

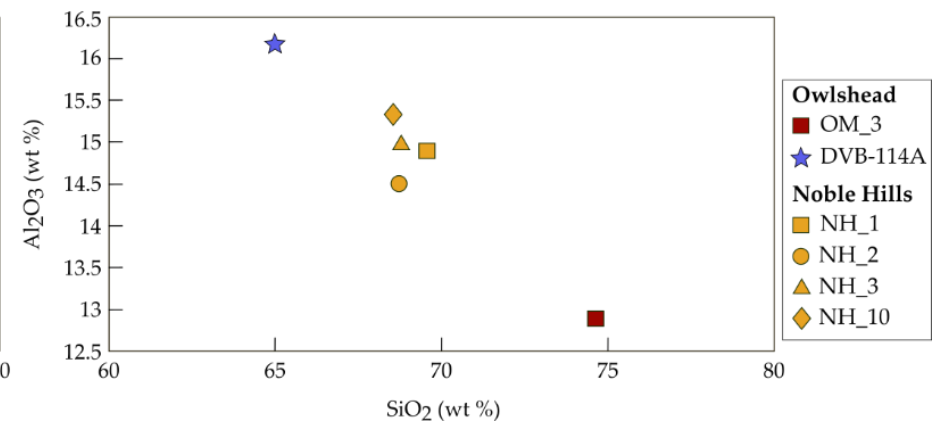

(b)

Figure 12. Harker diagrams showing the variation of (a) $\mathrm{K}_{2} \mathrm{O}$ [75] and (b) $\mathrm{Al}_{2} \mathrm{O}_{3}$ in the $\mathrm{OM}$ and $\mathrm{NH}$ granites. A sample from the OM analyzed by [34] is represented by the blue star.

The loss on ignition (LOI) is of $0.7 \mathrm{wt} \%$ for the OM granite and ranges from 1.1 to $2.8 \mathrm{wt} . \%$ for the NH granite (Table 5), showing that the OM granite contains less volatile elements than the NH granite, even for the freshest samples (NH_10, NH_1 and NH_2). By comparing the alteration degree of each sample estimated from optical observations of plagioclase and biotite (Table 5) and the LOI values, we note that a low LOI corresponds to a slight alteration, e.g., OM_3 or NH_2 and a high LOI corresponds to a more pronounced alteration, e.g., NH_3.

Table 5. Loss on ignition values compared to the alteration degree of plagioclase and biotite estimated under optical microscope.

\begin{tabular}{cccccc}
\hline Sample ID & OM_3 & NH_10 & NH_1 & NH_2 & NH_3 \\
\hline Loss on ignition (LOI) (wt.\%) & 0.7 & 1.5 & 1.7 & 1.1 & 2.8 \\
Alteration degree (\%) & 2 & 10 & 9 & 4 & 18 \\
Plagioclase alteration (\%) & 5 & 20 & 20 & 10 & 40 \\
Biotite alteration (\%) & 0 & 15 & 10 & 0 & 20 \\
\hline
\end{tabular}

In diagrams representing selected major elements versus the LOI (Figure 13), LOI values of $\mathrm{NH}$ samples show a positive correlation with $\mathrm{K}_{2} \mathrm{O}$ and a negative correlation with $\mathrm{Na}_{2} \mathrm{O}$ and $\mathrm{CaO}$. $\mathrm{SiO}_{2}$ and $\mathrm{Al}_{2} \mathrm{O}_{3}$ contents are approximately constant, 68.54-69.56 wt.\% and 14.53-15.36 wt.\% respectively. $\mathrm{MgO}$ content varies a lot (0.56-1.15 wt.\%) showing no clear correlation with the LOI. $\mathrm{K}_{2} \mathrm{O}$ and $\mathrm{Na}_{2} \mathrm{O}$ contents of the OM granite are equivalent to those of the freshest $\mathrm{NH}$ granites (NH_2, NH_10 and NH_1). However, the OM granite sample presents a higher amount of $\mathrm{SiO}_{2}$ and a lower amount of $\mathrm{Al}_{2} \mathrm{O}_{3}, \mathrm{CaO}$ and $\mathrm{MgO}$. The chemistry of the OM granite seems different from that of the NH granite regarding Figures 12 and 13 even though, according to [11], the NH granite derived from the OM granite. 

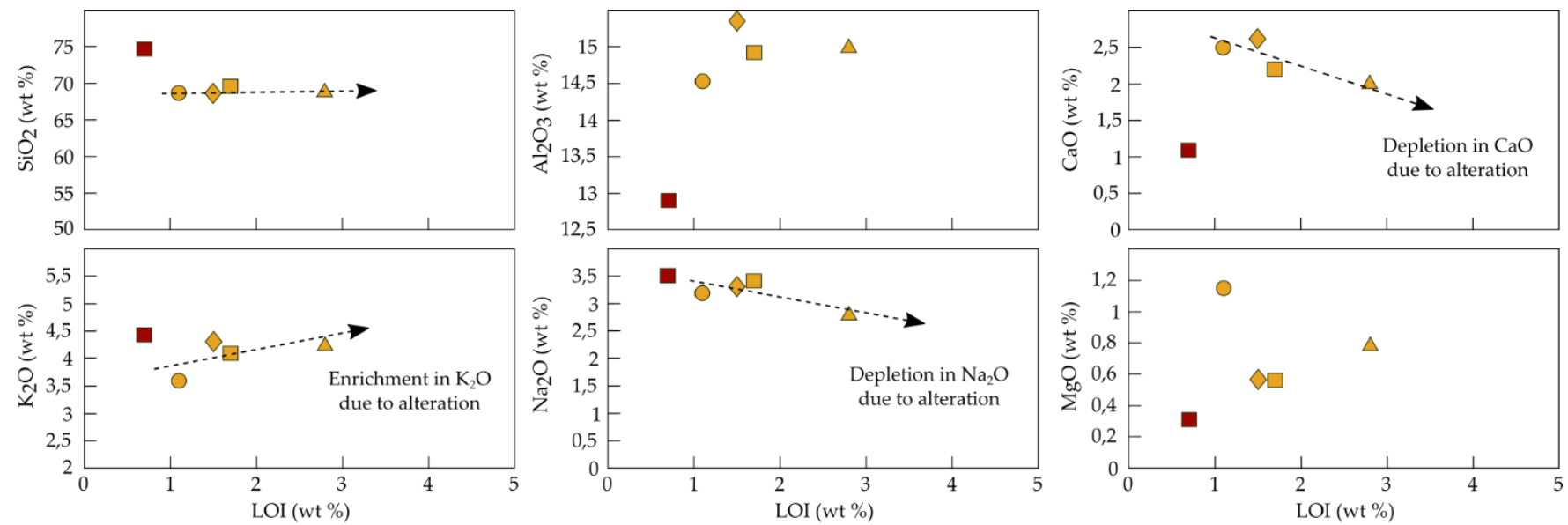

Owlshead Noble Hills

- OM_3 $\square$ NH_1 ONH_2 $\triangle$ NH_3 $\diamond$ NH_10

Figure 13. Plot of selected major element oxides $\left(\mathrm{SiO}_{2}, \mathrm{~K}_{2} \mathrm{O}, \mathrm{Al}_{2} \mathrm{O}_{3}, \mathrm{Na}_{2} \mathrm{O}, \mathrm{CaO}\right.$ and $\left.\mathrm{MgO}\right)$ versus LOI (loss on ignition).

4.2.2. Trace Element and REE Bulk Chemistry

Trace elements and Rare Earth Elements (REE) (Table 6) analyses were performed on the same samples as for major elements.

Table 6. Trace elements chemical composition of the Owlshead and Noble Hills granites.

\begin{tabular}{cccccc}
\hline Sample ID & OM_3 & NH_10 & NH_1 & NH_2 & NH_3 \\
\hline $\mathrm{Be}$ & \multicolumn{5}{c}{ Trace elements $(\mathrm{ppm})$} \\
$\mathrm{Co}$ & 2 & 2 & 2 & 3 & 2 \\
$\mathrm{Cs}$ & 1.5 & 4.2 & 2.9 & 6.4 & 3.5 \\
$\mathrm{Ga}$ & 1.6 & 2.4 & 1.1 & 3.4 & 1.8 \\
$\mathrm{Hf}$ & 15.6 & 16.7 & 16.0 & 17.2 & 14.1 \\
$\mathrm{Nb}$ & 4.3 & 3.6 & 4.1 & 4.6 & 4.6 \\
$\mathrm{Rb}$ & 22.3 & 13.8 & 11.4 & 18.9 & 10.5 \\
$\mathrm{Sn}$ & 154.7 & 144.9 & 103.0 & 139.9 & 115.7 \\
$\mathrm{Sr}$ & 2 & 1 & $<1$ & 2 & $<1$ \\
$\mathrm{Ta}$ & 116.2 & 275.2 & 237.5 & 268.2 & 182.7 \\
$\mathrm{Th}$ & 1.6 & 0.9 & 0.7 & 1.3 & 0.6 \\
$\mathrm{U}$ & 19.3 & 11.4 & 10.2 & 9.0 & 11.0 \\
$\mathrm{~V}$ & 1.8 & 2.2 & 1.5 & 1.4 & 1.5 \\
$\mathrm{~W}$ & 16 & 33 & 22 & 40 & 25 \\
$\mathrm{Zr}$ & $<0.5$ & $<0.5$ & 0.7 & $<0.5$ & $<0.5$ \\
$\mathrm{Y}$ & 139.8 & 134.2 & 156.6 & 180.6 & 159.0 \\
$\mathrm{Ba}$ & 19.7 & 22.5 & 17.5 & 21.4 & 17.0 \\
$\mathrm{Ni}$ & 554 & 1009 & 845 & 704 & 772 \\
$\mathrm{Sc}$ & $<20$ & $<20$ & $<20$ & $<20$ & $<20$ \\
$\mathrm{Cr}{ }_{2} \mathrm{O}_{3}$ & $<0.002$ & $<0.002$ & $<0.002$ & $<$ & 4 \\
$\mathrm{Be}$ & 2 & 2 & 2 & 3 & $<0.002$ \\
\hline & & 5 & 4 & 2 \\
\hline
\end{tabular}


Table 6. Cont.

\begin{tabular}{cccccc}
\hline Sample ID & OM_3 & NH_10 & NH_1 & NH_2 & NH_3 \\
\hline La & 52.1 & 28.3 & 26.2 & 21.7 & 26.8 \\
$\mathrm{Ce}$ & 97.0 & 53.0 & 48.1 & 40.8 & 52.2 \\
$\mathrm{Pr}$ & 9.97 & 5.93 & 5.31 & 4.59 & 5.62 \\
$\mathrm{Nd}$ & 31.7 & 20.6 & 18.8 & 16.6 & 19.5 \\
$\mathrm{Sm}$ & 5.29 & 3.82 & 3.51 & 3.56 & 3.48 \\
$\mathrm{Eu}$ & 0.53 & 0.89 & 0.89 & 0.81 & 0.81 \\
$\mathrm{Gd}$ & 4.24 & 3.66 & 3.14 & 3.60 & 3.22 \\
$\mathrm{~Tb}$ & 0.65 & 0.59 & 0.51 & 0.59 & 0.51 \\
$\mathrm{Dy}$ & 3.66 & 3.63 & 3.05 & 3.65 & 2.96 \\
$\mathrm{Ho}$ & 0.69 & 0.78 & 0.62 & 0.73 & 0.59 \\
$\mathrm{Er}$ & 2.05 & 2.25 & 1.87 & 2.18 & 1.81 \\
$\mathrm{Tm}$ & 0.30 & 0.33 & 0.28 & 0.33 & 0.27 \\
$\mathrm{Yb}$ & 2.08 & 2.32 & 1.77 & 2.16 & 1.86 \\
$\mathrm{Lu}$ & 0.33 & 0.37 & 0.28 & 0.36 & 0.28 \\
$\mathrm{TOT} / \mathrm{C}$ & 0.02 & 0.14 & 0.21 & 0.04 & 0.26 \\
$\mathrm{TOT} / \mathrm{S}$ & $<0.02$ & $<0.02$ & $<0.02$ & $<0.02$ & $<0.02$ \\
\hline
\end{tabular}

Chondrite-normalized REE patterns (Figure 14a) present enriched samples in light rare earth elements (LREE) relative to heavy rare earth elements (HREE) in both granites. However, the OW granite shows a higher abundance of LREE and a stronger negative $\mathrm{Eu}$ anomaly than the NH samples. In spite of different degrees of mineral alteration, all the NH samples follow the same trend. The primitive mantle-normalized multi-element diagram (Figure 14b) is characterized by distinct negative anomalies for $\mathrm{Nb}$ and $\mathrm{Sr}$ and high Th and U contents, typical for upper crustal composition [76]. They also show variable but high $\mathrm{Cs}, \mathrm{Rb}$ and Ba contents. More generally, samples are relatively rich in large-ion lithophile elements (LILEs) such as $\mathrm{Rb}, \mathrm{Ba}$, Th and $\mathrm{U}$, with $\mathrm{Sr}$ having the greatest depletion relative to the LILEs. High field strength elements (HFSEs) such as $\mathrm{Ta}, \mathrm{Nb}, \mathrm{Zr}$ and $\mathrm{Hf}$ are depleted compared to the LILEs. The OW granite shows, once again, a different trend compared to the $\mathrm{NH}$ samples. It has higher $\mathrm{Th}, \mathrm{Ta}, \mathrm{Nb}, \mathrm{La}, \mathrm{Ce}, \mathrm{Nd}$ and $\mathrm{Sm}$ contents and a lower Ba content. On both diagrams of Figure 14, the sample DVB-114A [34] shows a different pattern compared to OM_3.

(a)

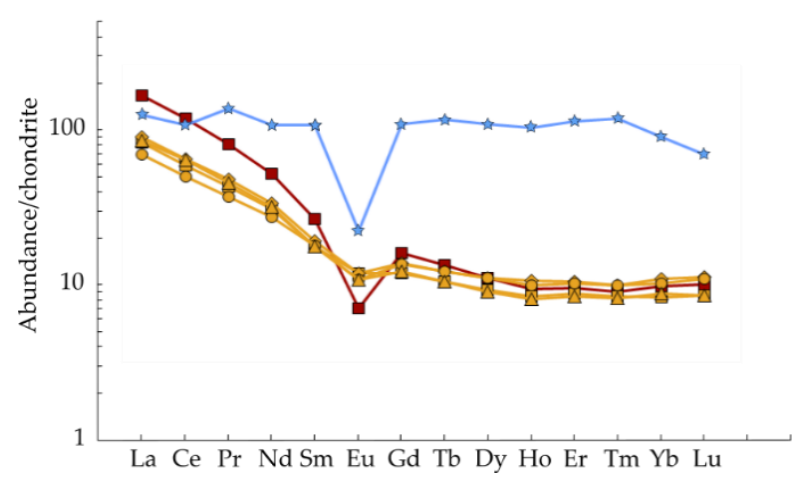

(b)

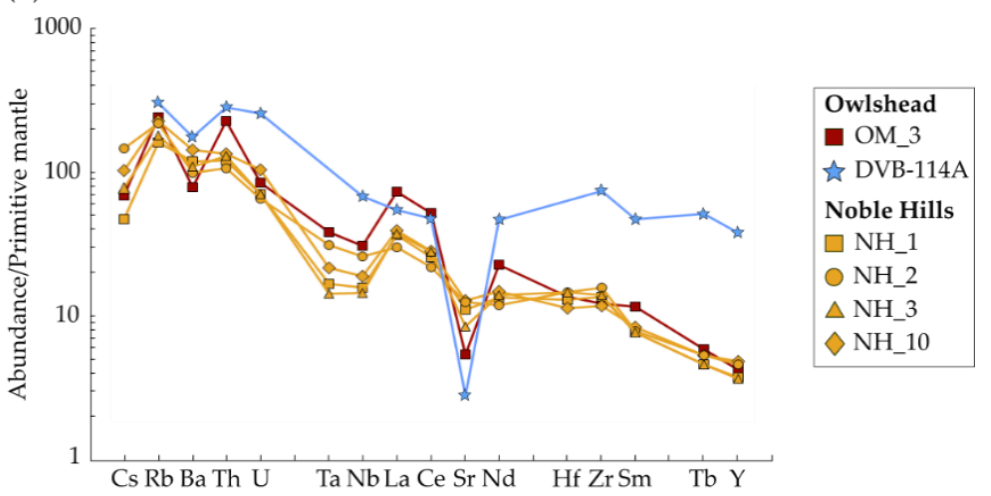

Figure 14. (a) Chondrite-normalized (values from [77]) rare earth element (REE) patterns of samples from the OM and the NH. (b) Primitive mantle-normalized (values from [78]'s slight revision of [79]) multi-element diagram showing trace element patterns of samples from the $\mathrm{OM}$ and the $\mathrm{NH}$. 


\subsection{Calcimetry and Porosimetry}

Calcite is present in all the samples, essentially linked to the alteration of the plagioclase. The calcite content is of $0.55 \%$ for the OM granite and ranges from 0.55 to $6.53 \%$ for the $\mathrm{NH}$ granite, with an average of $2.2 \%$ and a standard deviation of $1.64 \%$. The porosity is of $2.28 \%$ for the OM granite and ranges from 2.21 to $5.17 \%$ for the NH granite. A clear positive correlation can be seen between the calcite content and the LOI (Figure 15a). Positive correlations are also visible between the porosity and the LOI and between the porosity and the calcite content (Figure 15b,c). However, the sample NH_7 in Figure 15c is different. Having a low calcite content, it presents a higher porosity compared to the others. Those diagrams show that a low LOI corresponds to a low amount of calcite and a low porosity and that a low amount of calcite fits with a low porosity except for NH_7.
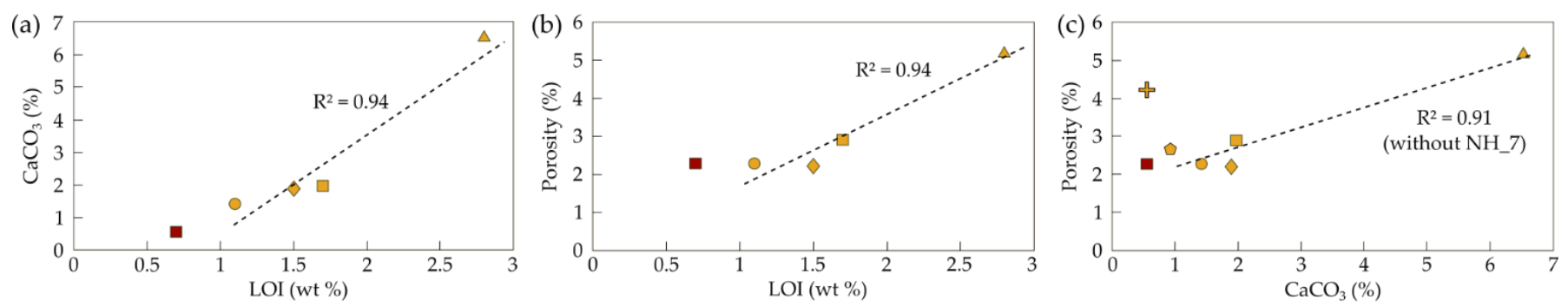

\begin{tabular}{|c|c|c|c|c|c|c|}
\hline Owlshead & Noble $\mathrm{Hi}$ & & & & & \\
\hline [ OM_3 & $\square$ NH_1 & ONH_2 & $\triangle \mathrm{NH}_{-} 3$ & $\triangle \mathrm{NH}_{-} 5$ & SH_7 & $\diamond \mathrm{NH} \_10$ \\
\hline
\end{tabular}

Figure 15. (a) Plot of the porosity versus the calcite content. (b) Plot of calcite content versus LOI (Loss on ignition). (c) Plot of porosity versus LOI.

\section{Discussion}

\subsection{Petrogenesis of the OM and NH Granites}

Bulk rock analyses of the $\mathrm{OM}$ and $\mathrm{NH}$ granites indicate for both of them a calc-alkaline, monzogranite composition, S-type in character (Figure 11). Rämö et al. (2002) [34] also investigated the $\mathrm{OM}$ in the same batholith, but south of our sampling area (blue star in Figure 2a). The comparison of geochemical data from their sample with the samples studied here, shows differences in terms of chemical composition (Figures 7, 11, 12 and 14). The OM seems to be a heterogenous pluton.

Chondrite-normalized REE patterns for the NH granite samples show the same trend (Figure 14a), but are different from the OM granite one. REE are relatively immobile during low-grade metamorphism and hydrothermal alteration [76]. The enrichment of the LREE and the depletion of Eu indicate the degree of magmatic differentiation the rock underwent. The Eu negative anomaly is attributed to the plagioclase fractionation involved in the setting of granites [80]. However, the breakdown of plagioclase and biotite can release some REE except Eu, which can be accommodated by illite formation [81].

The same observations were done through the primitive mantle-normalized spider diagrams, which shows variations in Ta and $\mathrm{Nb}$ contents of the $\mathrm{NH}$ samples (Figure 14b). Those variations are in good correlation with the LOI: the higher the LOI, the lower the $\mathrm{Nb}$ and Ta contents. Li et al. (2013) [82] observed $\mathrm{Nb} / \mathrm{Ta}$ ratios in altered domains in granitic rocks due to the $\mathrm{Nb}$ and Ta decreasing content during the illitization stage. The $\mathrm{LOI}$ is directly related to the percentage of alteration, the same phenomenon is observed in our samples. The depletion of $\mathrm{Sr}$ in the $\mathrm{NH}$ granite might be due to the alteration of magmatic primary plagioclase [82]. However, Sr content in OM is relatively low.

Those diagrams show and confirm the difference in terms of chemical composition between the $\mathrm{NH}$ and the $\mathrm{OM}$, which was suspected during thin sections observations. A comparison between our own chemical data within the OM and the data presented by [34] show substantial differences meaning that the OM granite is not homogeneous. Given the fact that the $\mathrm{NH}$ granite is considered as a transported part of the OM [11], it is therefore 
not surprising that the $\mathrm{NH}$ granite presents local composition variations. The OM samples are considered as representing the protolith prior to the mineral transformations identified in the $\mathrm{NH}$ granite.

Microcline was identified in the OM granite and only in the southern part of the $\mathrm{NH}$ indicating that this part of the range might have undergone a slower cooling than the northern part of the range or a warming.

\subsection{Thermal Evolution of the NH Granite}

Petrographic investigations have shown that plagioclase and sometimes biotite are replaced by illite. A recent study from [83] has confirmed that IC provides a useful method for characterizing regional grades of diagenesis and low-grade metamorphism. As already mentioned, in some conditions the alteration of a granite, resulting from fluid circulation, shows similarities with diagenetic reactions present in feldspathic sandstones [19], meaning that it is possible to characterize a regional grade by using the KI values obtained in granitic rocks.

As shown in Figure 2, the NH range is a structure stretched NW-SE. The KI values display a trend following this direction with decreasing values towards the south-east (Figure 10). KI values can be associated to different metamorphic zones corresponding to ranges of temperature (Table 1, [60]). The northwestern part of the range, characterized by high KI values, reveals mostly low-grade diagenesis tending progressively to highgrade diagenesis roughly toward the SE. A decrease of KI values indicates an increase in temperature [59]. Thus, this tendency reflects a temperature gradient increasing from the NW toward the SE. The elevation being higher in the south-east, with a higher temperature in this zone might indicate that the southern part of the range was more buried than the rest of the range and has been exhumed. A northeast-vergent contractional deformation is well expressed along the $\mathrm{NH}$ range in addition to the strike-slip deformation. It increases in intensity where the $\mathrm{NH}$ range converges with the Avawatz mountains ([38] and references therein), at the intersection between the SDVFZ and the GFZ [30]. Chabani et al. (2021) [12] have identified E-W structures in this area and they suppose that these structures are linked to the activity of the GFZ and the convergence of the Avawatz and the NH range. It is tempting to propose that this convergence implied the elevation of the topography at the southern part of the $\mathrm{NH}$ range. A work is in progress about exhumation history reconstruction by means of isotopic dating.

\subsection{Alteration Parageneses}

The $\mathrm{OM}$ and $\mathrm{NH}$ granites characterization reveals the presence of various secondary minerals as oxides, epidote, corrensite, K-white mica, calcite, kaolinite, illite/smectite mixed-layer and montmorillonite. Those minerals are well known as being the product of alteration processes due to the interaction of a circulating fluid with the surrounding rock. They are in equilibrium with the new environment in response to temperature, pressure and composition of the altering fluid [6,84-86]. In the $\mathrm{OM}$ and the $\mathrm{NH}$ granites, only plagioclase and biotite are affected. In the case of intense circulation, some primary minerals like plagioclase or biotite may be completely replaced. The newly formed minerals consist mainly in clay minerals [9]. According to optical observations, SEM-EDS and XRD analyses, two types of alteration processes have been identified in the $\mathrm{OM}$ and $\mathrm{NH}$ granites which are classified as (1) propylitic alteration and (2) argillic alteration. The characterization of the paragenesis and the alteration processes of the granites investigated in this study help to refine a part of the history of the OM and NH granitic basements (Figure 16). 


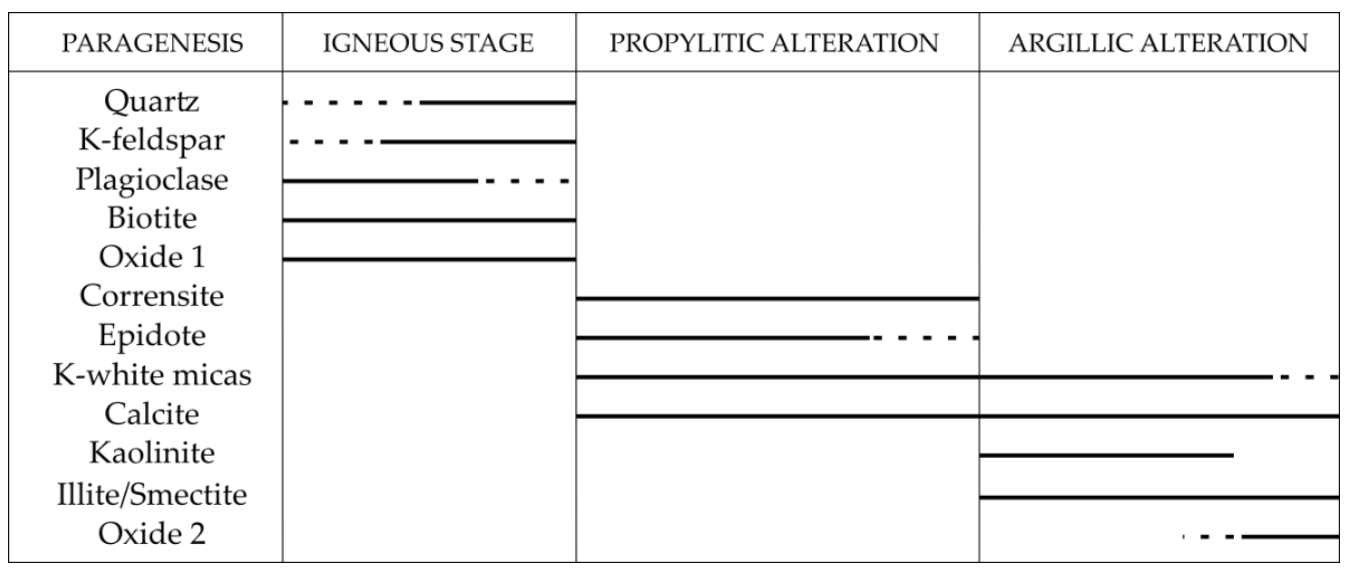

Figure 16. Paragenesis sequence and alteration evolution in the $\mathrm{OM}$ and $\mathrm{NH}$ granite.

\subsubsection{Propylitic Alteration}

The newly formed minerals depend on the composition of the host mineral. Corrensite, epidote, K-white micas, calcite and iron oxides were identified in the $\mathrm{OM}$ and $\mathrm{NH}$ granites (Figure 16) by means of optical observations, SEM-EDS and XRD analyses:

1. The calcite as in the OM granite occurs as infills of the microcracks without interacting with the surrounding rock, as well as at grain boundaries.

2. Mixed-layer clay minerals are the intermediate products of reactions involving endmember clays [87]. Corrensite, a chlorite/trioctahedral smectite mixed-layer phyllosicilate is considered as a stable mineral and also as an indicator of propylitic alteration $[86,88,89]$. It replaces partially biotite and occurs between $160-250{ }^{\circ} \mathrm{C}$ in geothermal fields $[6,84,90]$.

3. Epidote crystallization occurs around $220{ }^{\circ} \mathrm{C}$ [86]. It is also one major indicator of the propylitic alteration with corrensite [89].

4. The presence of $\mathrm{K}$-white mica flakes allows to fix temperatures around $230^{\circ} \mathrm{C}$ up to $350{ }^{\circ} \mathrm{C}[84,91]$.

All those secondary minerals occur at temperatures between approximately $160{ }^{\circ} \mathrm{C}$ and $350{ }^{\circ} \mathrm{C}$. The presence of corrensite and epidote is the major indicator of a stage of propylitic alteration. The propylitic alteration (Figure 17b) is considered as an earlier pervasive alteration stage. It is common at the margins of alteration zones produced at low fluid/rock ratio [6] and it takes place at the end of the crystallization of the granite [92]. The propylitic alteration results in the partial recrystallization of primary minerals (biotite and plagioclase) in secondary propylitic assemblages by interstitial fluids trapped into the grain boundaries during the cooling of the pluton [88]. Its effects are discrete, but both the $\mathrm{OM}$ and NH massifs are affected.

\subsubsection{Argillic Alteration}

Other newly formed mineral assemblages were identified only in the $\mathrm{NH}$ granite. They consist in illite + kaolinite + mixed-layers as illite/smectite (I/S) + calcite and oxide (Figure 16):

1. Illitic minerals are well known to be indicators of fluid circulation as well as paleocirculation systems [93]. [19,94] show that illite crystallization episodes can occur, for example, in a temperature range of 120 to $160^{\circ} \mathrm{C}$, corresponding to the argillic alteration facies. The illitization process mainly develops in plagioclase and biotite. It is a form of alteration product found extensively in granitoids, and felsic rocks, whereas K-feldspar remains relatively unaltered $[8,67,85]$.

2. According to [84], the presence of kaolinite in alteration paragenesis indicates a fluid temperature lower than $200-150^{\circ} \mathrm{C}$. Kaolinite is stable under more acidic conditions than illite, with $\mathrm{pH}$ values ranging from about 4.5 to 6 . It also represents a more 
advanced product of hydrolysis reaction due to a high $\mathrm{H}^{+}$activity in hydrothermal fluids.

3. The illite-rich (R3) I/S mixed-layer form around $150{ }^{\circ} \mathrm{C}[84,87]$, with more than $90 \%$ of illite based on [51].

4. Plagioclase, oligoclase in composition, presents patches of calcite. Those patches are interpreted as a product of Ca release due to plagioclase alteration.

5. Oxides can be present along the cleavages of the altered biotite. They are interpreted as the result of $\mathrm{Mg}$ and Fe release during biotite alteration.

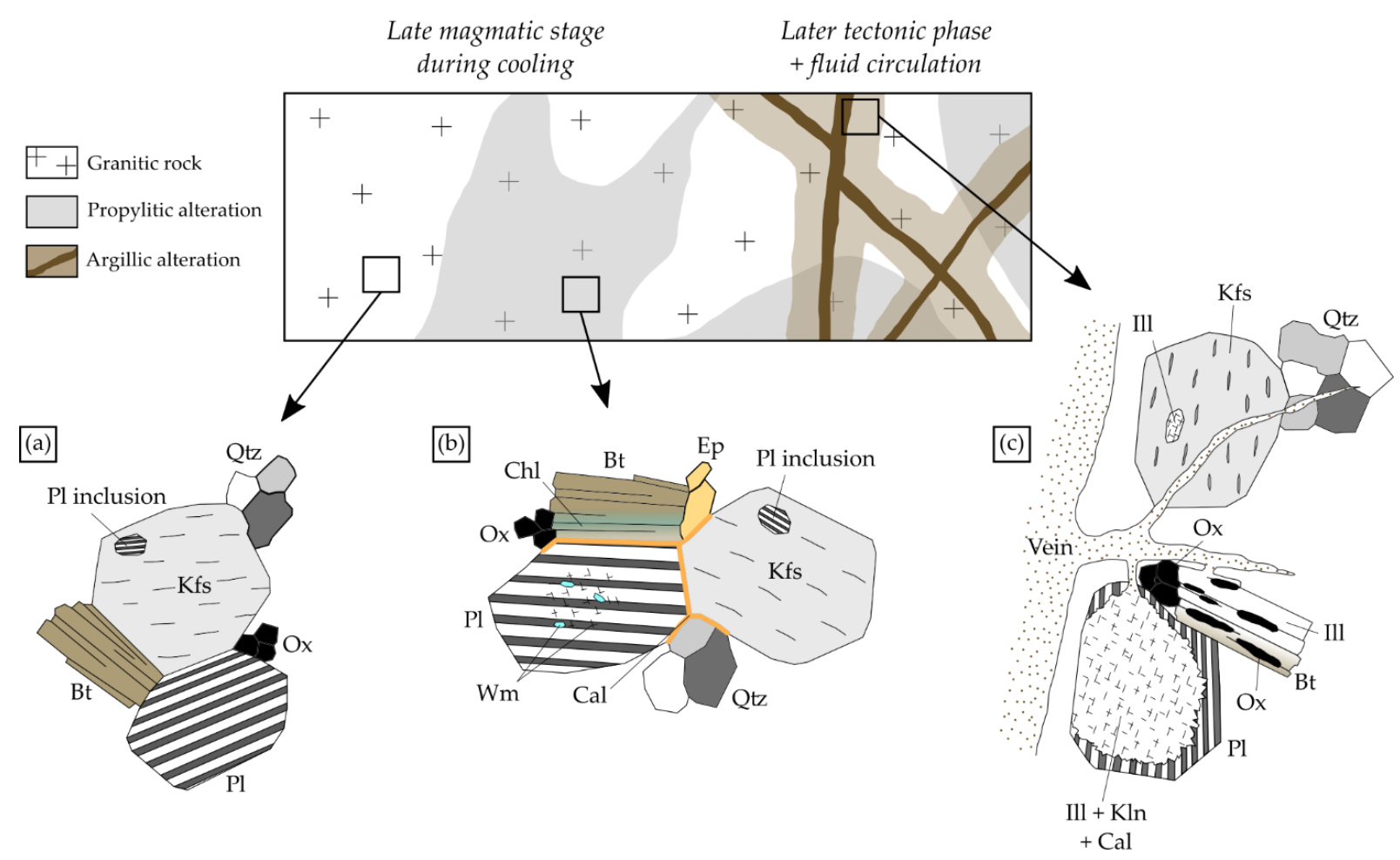

Figure 17. Schematic representation of the different alteration processes which can be observed in the OM and NH granites. (a) Fresh granite non-affected by alteration. (b) Granite affected by the propylitic alteration showing the slight chloritization of biotite and the crystallization of K-white micas in the core of plagioclase. (c) Granite affected by the argillic alteration and localized along fractures where fluid has circulated. Biotite are locally completely transformed into illite and plagioclase into illite, calcite and/or kaolinite. Perthites and inclusions in K-feldspars can also be altered. Abbreviations (except for "Ox and $\mathrm{Wm}^{\prime \prime}$ ) after [45]: Bt—Biotite, Cal—Calcite, Chl—Chlorite, Ep—Epidote, Ill—Illite, Kln—Kaolinite, Kfs—K-feldspar, Ox-Oxide, Pl—Plagioclase, Qtz-Quartz, Wm-K-white mica.

Plagioclase and quartz form an interconnected skeleton through the texture. The difference of physical and chemical behaviors between both minerals results in different types of porosity. Quartz shows microcracks and plagioclase shows dissolution pits (Figure 18). Ref. [95] observed the same in the Soultz-sous-Forêts granite. They also showed that the exchange surface between plagioclase and a fluid is around 20 times higher than in quartz. As a consequence, they assume that all the pores are interconnected in plagioclase. They considered this mineral as the main path for fluid flow. Thus, this can be also available in the NH granite. K-feldspar is not affected by the alteration, but perthites and mineral inclusions present in the K-feldspars can be dissolved. 


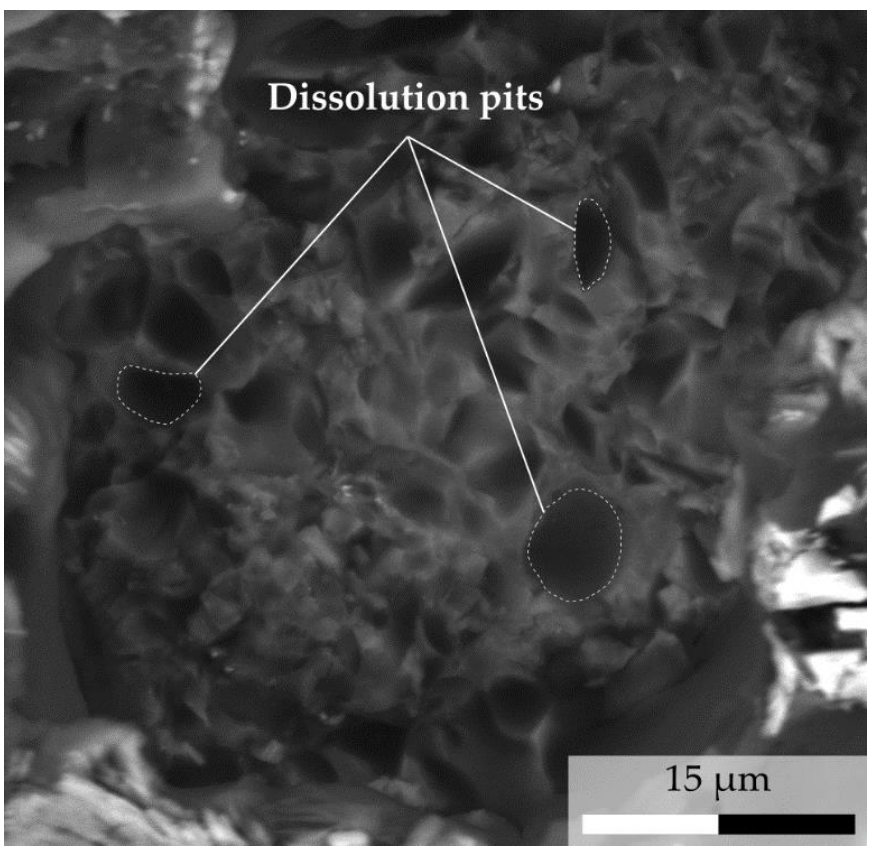

Figure 18. Back-scattered image showing a magnified view of plagioclase dissolution pits under SEM $(15 \mathrm{kV} 5.3 \mathrm{~mm} \times 1.7 \mathrm{k}$ BSECOMP).

The crystallization of these minerals occurs at temperature between 130 and $200{ }^{\circ} \mathrm{C}$. This range of temperature corresponds to the stage of argillic alteration [84]. The argillic alteration (Figure 17c) consists into the chemical leaching and clay enrichment processes produced at lower temperatures $[19,88,96]$. This alteration is known as a vein alteration organized in the vicinity of fractures where fluids have circulated $[86,88]$.

\subsubsection{Evidences of Weathering}

XRD analyses on an oriented sample of the clay fraction from the OM reveal the presence of Montmorillonite (Mnt) (Figure 8). Mnt, a common smectite pattern, results either from argillic (vein) alteration [84,89] or from weathering [97,98]. As described above, the OM granite appears as "fresh" from (1) field observations: no veins were observed at outcrop scale and macro-scale and the granite appears competent, (2) thin-section analyzes: no veins or veinlets, calcite crystallizations are only present at grain boundaries, and (3) geochemical analyzes, which indicate a very low LOI (0.7 wt.\%). No vein was observed at any scale and secondary minerals are all characteristic of propylitic alteration. Those data show that the Mnt cannot result from argillic alteration. In the case of the OM granite, the Mnt is interpreted as a signature of weathering. As its amount is low (15\% of the clay fraction), the global alteration of the granite is considered as being dominated by the propylitic alteration. With the OM being considered as the protolith, weathering can be considered negligible in both $\mathrm{OM}$ and $\mathrm{NH}$ granites.

\subsubsection{Alteration Stage Occurrences}

The OM granite presents evidence of propylitic alteration only, while the NH granite presents both propylitic and argillic facies. The argillic facies seems most of the time to overprinting the propylitic facies. However, some samples present only evidence of argillic alteration. In those cases, either the propylitic facies have either completely disappeared, or some zones were not initially affected by the propylitic alteration. Some minerals, such as illite and kaolinite, crystallize during the argillic alteration under different conditions [84]. This suggests that several episodes of alteration could have occurred in the $\mathrm{NH}$ granite. Afterward, weathering can occur at ambient temperature, when the granite was exhumed. These alteration overprints result also in a retrograde evolution in terms of temperature $(\mathrm{T})$ with T propylitic $>\mathrm{T}$ argillic $>\mathrm{T}$ weathering. 
In the NH granite, the argillic alteration seems to be associated to fracturing. A fresh granitic rock is not permeable enough to allow fluid circulation [6]. This suggests that the development of fractures is an important factor allowing fluid to circulate [6], the observation that the freshest NH granite is more altered than the one from the OM (Figure 3) can be related to the fact that the NH lie along an important shear corridor. None of NH samples considered in the present study are fracture free, even though they were collected far from the faults, and each of them shows evidences of argillic alteration. In spite of the low fracture density the existing number of microfractures is enough to allow fluid to significantly percolate through the host rocks and chemically interact with it. A second paper (PART 2, this issue) focusses on the role of the fracture system on the granite alteration processes.

\subsection{Effects of Alteration on Petrogaphic and Petrophysical Behaviour}

Petrographic observations and the range of LOI (0.7-4.1 wt.\%) values confirm that the NH granite experienced alteration. LOI is so directly related to the degree of mineral alteration as done by $[99,100]$. Mineral changes being related to the propylitic and argillic alterations, the LOI can be defined in this study as a monitor for alteration processes. The effects of alteration on element transfers can be evaluated thanks to the diagrams plotting $\mathrm{SiO}_{2}, \mathrm{Al}_{2} \mathrm{O}_{3}, \mathrm{CaO}, \mathrm{K}_{2} \mathrm{O}, \mathrm{Na}_{2} \mathrm{O}$ and $\mathrm{MgO}$ against LOI (Figure 13). In Figure 13, the $\mathrm{K}_{2} \mathrm{O}$, $\mathrm{Na}_{2} \mathrm{O}, \mathrm{CaO}$ and $\mathrm{MgO}$ define a broad correlation with LOI, indicating that they may have been mobile during alteration [99]. The $\mathrm{NH}$ granite shows that $\mathrm{Na}_{2} \mathrm{O}$ and $\mathrm{CaO}$ have a negative correlation which can be related to the alteration of the plagioclase (oligoclase initial composition). Indeed, plagioclase can be depleted in $\mathrm{Na}$ and $\mathrm{Ca}$ mobile elements when it interacts with a fluid [101]. Likewise, the $\mathrm{K}_{2} \mathrm{O}$ is observed in alteration products of plagioclase as illite and shows an enrichment with the LOI increase. Newly formed minerals, as presented above, are related to the recrystallization of the plagioclase as a result of its interaction with the fluid. As for the $\mathrm{CaO}$ and $\mathrm{MgO}$ contents, they remain high compared to the OM granite. This can be linked to an external contribution. In a whole, the NH granite was affected by an alkali alteration, which results in major compositional changes. Thus, all the elements, Si and Al excepted, have partly left the system, meaning that the system is open. Their content differences in the NH granite compared to the OM granite could be explained by the depletion of the most mobile elements during the alteration of the NH granite. This can so influence the percentage of each element. Otherwise, it can be suggested that the visible variations of $\mathrm{SiO}_{2}$ and $\mathrm{Al}_{2} \mathrm{O}_{3}$ were controlled by protolith composition rather than alteration processes.

Link alteration degree and amount of calcite is difficult since petrographic analyses of the samples is qualitative. However, Figure 15a shows a positive correlation between LOI and calcite content. Ledésert et al. (2009) [61] show that calcite can be encountered in high amount in altered zones. Thus, in the NH, the correlation shows that the higher the calcite content, the higher the degree of alteration and vice versa. In the same way, LOI can be related to porosity (Figure 15b) with a low LOI linked to low porosity (NH_1, NH_2 and NH_10) and high LOI linked to as high porosity (NH_3). Therefore, the increase of porosity is also linked to the increase of alteration. Studies [102,103] showed that the porosity increases from unaltered to altered granite. Figure $15 \mathrm{c}$ shows a similar correlation between the calcite content and the porosity. Samples having a low calcite content (NH1, NH_2, NH_5 and NH_10) present a low porosity, while NH_3 has a high calcite content associated with a high porosity. One exception can be observed. The sample NH_7 presents a low calcite content for a high porosity. This can be explained by the presence of larger microfractures compared to the other samples, which increase the porosity. Thus, it is not always possible to link the porosity to the calcite content. According to [104], the average calcite content of a fresh granite is $0.252 \mathrm{wt} . \%$, and does not exceed $1.8 \mathrm{wt} . \%$. As a consequence, measurements over this last value can be regarded as a calcite anomaly, and so are representative of a granite affected by argillic alteration, which may be a sign of paleo fluid flow [94]. Ten samples out of fifteen from the NH have a calcite content higher 
than 1.8 wt.\%. This suggests that the OM and some zones of the NH were not affected by the argillic alteration, but only by the propylitic one. By considering the calcite content average of $2.2 \%$ for the $\mathrm{NH}$, those data also indicate that even if the samples were collected far from the major faults, the granite can be affected by argillic alteration.

\subsection{The NH: A Paleo-Geothermal Reservoir?}

In the present contribution we have given numerous pieces of evidences for a pervasive alteration of the $\mathrm{NH}$ granite. Ubiquitous argillic alteration affecting plagioclase and biotite is present. The K-feldspar being unaltered, potassium enrichment by incoming fluids is necessary to produce abundant amount of illite. The high concentration of calcite, in some samples, requires an external input of $\mathrm{Ca}$, which cannot come only from the plagioclase alteration. Due to this alteration, the rock porosity was drastically enhanced by dissolution of the plagioclase. Porosity is also enhanced by the microfracturing well visible in quartz and K-feldspar, which is related to the activity of the SDVFZ. It is believed that this microfracturing drastically enhanced interaction surfaces between minerals and fluids allowing chemical elements exchanges between hydrothermal fluids and the granite. The strain is not homogeneously distributed in the NH. The NH granite is affected either by non-localized deformation (samples from this study) or by strain concentrations along fault zones that will be presented in the accompanying contribution (PART 2, this issue).

Our results have shown that an alteration of vast volumes of rocks is thus possible, even outside localized high strain zones. All these data are in favor of a hydrothermal fluid percolation, which is encountered in an exploited geothermal reservoir [6,19]. A geothermal reservoir consisting into a flow system where a high amount of hot fluid is stored and circulates through the rock, and our results encourage to consider the $\mathrm{NH}$ as a paleo-geothermal reservoir.

\section{Conclusions}

The NH were chosen in the framework of the H2020 MEET project as being an opportunity to characterize a granitic paleo-geothermal reservoir in a trans-tensional context. Arid conditions and a 3D exposure were important criteria allowing the thorough characterization of the granite. The aim of this study was to characterize the granite pervasive alteration processes, away from the fractures, in terms of changes of mineralogical, geochemical and related petrophysical properties.

Illite was identified by XRD in all the NH samples, allowing to obtain KI values which revealed a NW-SE temperature gradient through the range. This gradient might be considered as a sign of a possible exhumation of the southern part of the range due to the interaction with the Avawatz Mountains.

The partial recrystallization of plagioclase and biotite into newly formed minerals, due to fluid/rock interactions, was identified as reflecting three types of alteration:

1. A pervasive propylitic alteration. This alteration is present in the OM granite (the freshest one considered as the protolith) and in the NH granite and characterized by the presence of corrensite and/or epidote.

2. A local argillic alteration. This alteration was identified only locally in the NH granite by the occurrence of clay minerals such as kaolinite, illite/smectite mixed-layers and illite, all of which crystallize at a lower temperature than the propylitic alteration. Kaolinite and illite might reflect a different amount of leaching or different $\mathrm{pH}$, meaning that several fluids have circulated.

3. Weathering identified in the OM granite by the presence of montmorillonite, thus formed at surface temperature.

The NH granite alteration was highlighted by optical observations. In addition, geochemistry also provided data to support them. Indeed, depletion of $\mathrm{Na}$ and $\mathrm{Ca}$ was observed with the increase of LOI, considered as a good indicator of the amount of alteration of plagioclase alteration. At the same time, K enrichment was observed with the increase of LOI, and linked to illite crystallization. Calcimetry performed on the NH granite 
samples showed a calcite content often higher than the $1.8 \%$ value, admitted as being the maximum in a fresh granite. These values tend to increase with the LOI, confirming that the NH granite underwent alteration. Porosity also shows a positive correlation with the LOI indicating that the porosity increases with the amount of alteration. However, its correlation with the calcite content is less obvious, as calcite might crystallize in the porosity and thus reduce it.

The $\mathrm{NH}$ granite underwent up to two stages of alteration before being exposed to surface conditions, showing a retrograde evolution. It was observed petrographically that the argillic alteration overprinted the propylitic alteration, until its signature is lost. The weathering signal is low ( $15 \%$ of the clay fraction) and considered as negligible in the $\mathrm{OM}$. The OM being considered as the protolith of the $\mathrm{NH}$, the contribution of weathering is also considered as negligible in the NH granite, where no montmorillonite was found. The newly formed minerals are thus considered as being the product of hydrothermal alteration and not of weathering.

This study provides multiple evidence allowing the consideration of the $\mathrm{NH}$ granite as a paleo-geothermal reservoir.

The activity of a geothermal reservoir is a combination of pervasive circulation within nearly strain-free zones (as shown in the present contribution), as well as fractured domains where high strain is accumulated. Our study is therefore completed by a PART 2 (this issue), in which the same investigation approach is dedicated to samples taken within visibly fractured zones.

Author Contributions: Conceptualization, J.K., S.P., B.A.L., R.L.H., A.C. and G.T.; methodology, J.K., S.P., B.A.L., R.L.H., A.C. and G.T.; software, J.K.; validation, S.P., B.A.L., R.L.H., A.C., P.B. and G.T.; formal analysis, J.K.; investigation, J.K., S.P., B.A.L., R.L.H. and G.T.; resources, J.K.; data curation, J.K., S.P., B.A.L., R.L.H., A.C. and G.T.; writing-original draft preparation, J.K.; writing-review and editing, S.P., B.A.L., R.L.H., A.C., G.T. and P.B. and H2020 MEET consortium; visualization, S.P., B.A.L., R.L.H., A.C., G.T. and P.B.; supervision, J.K.; project administration, G.T.; funding acquisition, G.T. and H2020 MEET consortium. All authors have read and agreed to the published version of the manuscript.

Funding: This project has received funding from the European Union's Horizon 2020 research and innovation program under grant agreement No 792037 (H2020 MEET project).

Data Availability Statement: Not applicable.

Acknowledgments: This manuscript was prepared as a contribution to the PhD thesis (Institut Polytechnique UniLaSalle Beauvais) of Johanne Klee, which was funded by the European Union's Horizon 2020 research and innovation program under grant agreement No 792037 (H2020 MEET project). The authors are grateful to Terry Pavlis for his knowledge and helpful discussions about the regional geology of Death Valley and the Noble Hills. We also acknowledge Albert Genter for the fruitful exchanges about granite alteration processes. We thank Thi Tuyen Nguyen, Elena Pavlovskaia, Carl Tixier and Chloé Gindrat for their help for analyses. Helpful comments and the validation of the manuscript by the H2020 MEET consortium are gratefully acknowledged. We finally would like to thank Catherine Lerouge and the anonymous reviewer for their help and remarks to improve this manuscript.

Conflicts of Interest: The authors declare no conflict of interest.

\section{References}

1. Williams, C.F.; Reed, M.J.; Anderson, A.F. Updating the classification of geothermal resources. In Proceedings of the Thirty Sixth Workshop on Geothermal Reservoir Engineering Standford University, Standford, CA, USA, 31 January-2 February 2011.

2. Moeck, I.S. Catalog of geothermal play types based on geologic controls. Renew. Sustain. Energy Rev. 2014, 37, 867-882. [CrossRef]

3. Olasolo, P.; Juárez, M.C.; Morales, M.P.; D’Amico, S.; Liarte, I.A. Enhanced Geothermal Systems (EGS): A Review. Renew. Sustain. Energy Rev. 2016, 56, 133-144. [CrossRef]

4. Trullenque, G.; Genter, A.; Leiss, B.; Wagner, B.; Bouchet, R.; Leoutre, E.; Malnar, B.; Bär, K.; Rajšl, I. Upscaling of EGS in different geological conditions: A European perspective. In Proceedings of the 43rd Workshop on Geothermal Reservoir Engineering Standford University, Standford, CA, USA, 12-14 February 2018; p. 10. 
5. Faulds, J.E.; Hinz, N.H.; Dering, G.M.; Siler, D.L. The hybrid model-The most accommodating structural setting for geothermal power generation in the Great Basin, Western USA. Geotherm. Resour. Counc. Trans. 2013, 37, 3-10.

6. Nishimoto, S.; Yoshida, H. Hydrothermal alteration of deep fractured granite: Effects of dissolution and precipitation. Lithos 2010, 115, 153-162. [CrossRef]

7. Dezayes, C.; Lerouge, C. Reconstructing paleofluid circulation at the hercynian basement/mesozoic sedimentary cover interface in the Upper Rhine Graben. Geofluids 2019, 2019, 1-30. [CrossRef]

8. Plumper, O.; Putnis, A. The complex hydrothermal history of granitic rocks: Multiple feldspar replacement reactions under subsolidus conditions. J. Petrol. 2009, 50, 967-987. [CrossRef]

9. Inoue, A. Formation of clay minerals in hydrothermal environments. In Origin and Mineralogy of Clays; Velde, B., Ed.; Springer: Berlin/Heidelberg, Germany, 1995; pp. 268-329. ISBN 978-3-642-08195-8.

10. Burchfiel, B.C.; Stewart, J.H. "Pull-apart" origin of the central segment of Death Valley, California. GSA Bull. 1966, 77, 439-442. [CrossRef]

11. Pavlis, T.L.; Trullenque, G. Evidence for $40-41 \mathrm{~km}$ of dextral slip on the Southern Death Valley fault: Implications for the Eastern California shear zone and extensional tectonics. Geology 2021, 49, 767-772. [CrossRef]

12. Chabani, A.; Trullenque, G.; Ledésert, B.A.; Klee, J. Multiscale Characterization of fracture patterns: A case study of the Noble Hills Range (Death Valley, CA, USA), application to geothermal reservoirs. Geosciences 2021, 11, 280. [CrossRef]

13. Kisch, H.J. Correlation between indicators of very low-grade metamorphism. In Low Temperature Metamorphism; Frey, M., Ed.; Chapman \& Hall: London, UK, 1987; pp. 227-300.

14. Árkai, P.; Sassi, F.; Desmons, J. Very low- to low-grade metamorphic rocks. In Metamorphic Rocks A Classification and Glossary Terms; Cambridge University Press: Cambridge, UK, 2007.

15. Frey, M. Very low-grade metamorphism of clastic sedimentary rocks. In Low Temperature Metamorphism; Chapman \& Hall: London, UK, 1987; pp. 9-58.

16. Árkai, P.; Maehlmann, R.; Suchy, V.; Balogh, K.; Sykorová, I.; Frey, M. Possible Effects of Tectonic Shear Strain on Phyllosilicates: A Case Study from the Kandersteg Area, Helvetic Domain, Central Alps, Switzerland. TMPM Tschermaks Mineral. Petrogr. Mitt. 2002, 82, 273-290.

17. Mullis, J.; Mählmann, R.F.; Wolf, M. Fluid Inclusion Microthermometry to Calibrate Vitrinite Reflectance (between 50 and $270{ }^{\circ} \mathrm{C}$ ), Illite Kübler-Index Data and the Diagenesis/Anchizone Boundary in the External Part of the Central Alps. Appl. Clay Sci. 2017, 143, 307-319. [CrossRef]

18. Ferreiro Mählmann, R.; Bozkaya, Ö.; Potel, S.; le Bayon, R.; Šegvić, B.; Nieto, F. The Pioneer Work of Bernard Kübler and Martin Frey in Very Low-Grade Metamorphic Terranes: Paleo-Geothermal Potential of Variation in Kübler-Index/Organic Matter Reflectance Correlations. A Review. Swiss. J. Geosci. 2012, 105, 121-152. [CrossRef]

19. Ledésert, B.; Berger, G.; Meunier, A.; Genter, A.; Bouchet, A. Diagenetic-Type Reactions Related to Hydrothermal Alteration in the Soultz-Sous-Forets Granite, France. Eur. J. Mineral. 1999, 11, 731-741. [CrossRef]

20. Wernicke, B.; Axen, G.J.; Snow, J.K. Basin and Range Extensional Tectonics at the Latitude of Las Vegas, Nevada. GSA Bull. 1988, 100, 1738-1757. [CrossRef]

21. Wright, L. Late Cenozoic Fault Patterns and Stress Fields in the Great Basin and Westward Displacement of the Sierra Nevada Block. Geology 1976, 4, 489-494. [CrossRef]

22. Wernicke, B.; Spencer, J.E.; Burchfiel, B.C.; Guth, P.L. Magnitude of Crustal Extension in the Southern Great Basin. Geology 1982, 10, 499-502. [CrossRef]

23. Stewart, J.H. Extensional Tectonics in the Death Valley Area, California: Transport of the Panamint Range Structural Block 80 Km Northwestward. Geology 1983, 11, 153-157. [CrossRef]

24. Calzia, J.P.; Rämö, O.T. Late Cenozoic Crustal Extension and Magmatism, Southern Death Valley Region, California. GSA Field Guides 2000, 2, 135-164. [CrossRef]

25. Norton, I. Two-Stage Formation of Death Valley. Geosphere 2011, 7, 171-182. [CrossRef]

26. Luckow, H.; Pavlis, T.; Serpa, L.; Guest, B.; Wagner, D.; Snee, L.; Hensley, T.; Korjenkov, A. Late Cenozoic Sedimentation and Volcanism during Transtensional Deformation in Wingate Wash and the Owlshead Mountains, Death Valley. Earth Sci. Rev. 2005, 73, 177-219. [CrossRef]

27. Hill, M.L.; Troxel, B.W. Tectonics of Death Valley Region, California. GSA Bull. 1966, 77, 435-438. [CrossRef]

28. Butler, P.R.; Troxel, B.W.; Verosub, K.L. Late Cenozoic History and Styles of Deformation along the Southern Death Valley Fault Zone, California. GSA Bull. 1988, 100, 402-410. [CrossRef]

29. Brady, R.H., III. Cenozoic Geology of the Northern Avawatz Mountains in Relation to the Intersection of the Garlock and Death Valley Fault Zones, San Bernardino County, California. Ph.D. Thesis, University of California, Berkeley, CA, USA, 1986.

30. Brady, R.H.; Clayton, J.; Troxel, B.W.; Verosub, K.L.; Cregan, A.; Abrams, M. Thematic Mapper and Field Investigations at the Intersection of the Death Valley and Garlock Fault Zones, California. Remote Sens. Environ. 1989, 28, 207-217. [CrossRef]

31. Lifton, Z.M.; Newman, A.V.; Frankel, K.L.; Johnson, C.W.; Dixon, T.H. Insights into Distributed Plate Rates across the Walker Lane from GPS Geodesy. Geophys. Res. Lett. 2013, 40, 4620-4624. [CrossRef]

32. Nagorsen-Rinke, S.; Lee, J.; Calvert, A. Pliocene Sinistral Slip across the Adobe Hills, Eastern California-Western Nevada: Kinematics of Fault Slip Transfer across the Mina Deflection. Geosphere 2013, 9, 37-53. [CrossRef] 
33. Miller, M.B.; Wright, L.A. Geology of Death Valley National Park, 3rd ed.; Kendall Hunt Publishing Company: Dubuque, IA, USA, 2015

34. Rämö, T.O.; Calzia, J.P.; Kosunen, P.J. Geochemistry of Mesozoic Plutons, Southern Death Valley Region, California: Insights into the Origin of Cordilleran Interior Magmatism. Contrib. Mineral. Petrol. 2002, 143, 416-437. [CrossRef]

35. Troxel, B.W.; Butler, P.R. Rate of Cenozoic Slip on Normal Faults, South-Central Death Valley, California; Department of Geology, University of California: Berkeley, CA, USA, 1979.

36. Butler, P.R. Geology: Structural History and Fluvial Geomorphology of the Southern Death Valley Fault Zone, Inyo and San Bernardino Counties, California. Ph.D. Thesis, University of California, Davis, CA, USA, 1984.

37. Brady, R.H.; Troxel, B.W. Stratigraphy and Tectonics of the Northern Avawatz Mountains at the Intersection of the Garlock and Death Valley Fault Zones, San Bernardino County, California. In Quaternary Tectonics of Southern Death Valley, California-Field Trip Guide: Shoshone, California, Friends of the Pleistocene, Pacific Cell; USGS: Shoshone, CA, USA, 1986; pp. 1-12.

38. Niles, J.H. Post-Middle Pliocene Tectonic Development of the Noble Hills, Southern Death Valley, California. Ph.D. Thesis, San Francisco State University, San Francisco, CA, USA, 2016.

39. Mahon, R.C.; Dehler, C.M.; Link, P.K.; Karlstrom, K.E.; Gehrels, G.E. Detrital Zircon Provenance and Paleogeography of the Pahrump Group and Overlying Strata, Death Valley, California. Precambrian Res. 2014, 251, 102-117. [CrossRef]

40. DeCelles, P.G. Late Jurassic to Eocene Evolution of the Cordilleran Thrust Belt and Foreland Basin System, Western USA. Am. J. Sci. 2004, 304, 105-168. [CrossRef]

41. Stamm, J.F. Geology at the Intersection of the Death Valley and Garlock Fault Zones, Southern Death Valley, California. Ph.D. Thesis, Pennsylvania State University, State College, PA, USA, 1981.

42. Klee, J.; Trullenque, G.; Ledésert, B.; Potel, S.; Hébert, R.; Chabani, A.; Genter, A. Petrographic analyzes of fractured granites used as an analogue of the soultz-sous-forêts geothermal reservoir: Noble Hills, CA, USA. In Proceedings of the Extended Abstract, Reykjavik, Iceland, 26 May 2021.

43. Troxel, B.W. Right-Lateral Offset of ca. $28 \mathrm{Km}$ along a Strand of the Southern Death Valley Fault Zone. Calif. Geol. Soc. Am. Abstr. Programs 1994, 26, 99.

44. Castaing, C.; Rabu, D. Apports de La Géologie à La Recherche et à l'Exploitation de Pierres de Taille (Roches Ornementales et de Construction). Available online: https:/ / hal.archives-ouvertes.fr/hal-01860154 (accessed on 12 July 2021).

45. Kretz, R. Symbols for Rock-Forming Minerals. Am. Mineral. 1983, 68, 277-279.

46. Bisdom, K.; Gauthier, B.D.M.; Bertotti, G.; Hardebol, N.J. Calibrating Discrete Fracture-Network Models with a Carbonate Three-Dimensional Outcrop Fracture Network: Implications for Naturally Fractured Reservoir Modeling. AAPG Bull. 2014, 98, 1351-1376. [CrossRef]

47. Gillespie, P.A.; Howard, C.B.; Walsh, J.J.; Watterson, J. Measurement and Characterisation of Spatial Distributions of Fractures. Tectonophysics 1993, 226, 113-141. [CrossRef]

48. Schmidt, D.; Schmidt, S.T.; Mullis, J.; Ferreiro Mählmann, R.; Frey, M. Very Low Grade Metamorphism of the Taveyanne Formation of Western Switzerland. Contrib. Mineral. Petrol. 1997, 129, 385-403. [CrossRef]

49. Kisch, H.J. Illite Crystallinity: Recommendations on Sample Preparation, X-ray Diffraction Settings, and Interlaboratory Samples. J. Metamorph. Geol. 1991, 9, 665-670. [CrossRef]

50. Ferreiro Mählmann, R.; Frey, M. Standardisation, Calibration and Correlation of the Kübler-Index and the Vitrinite/Bituminite Reflectance: An Inter-Laboratory and Field Related Study. Swiss J. Geosci. 2012, 105, 153-170. [CrossRef]

51. Moore, D.M.; Reynolds, R.C. X-ray diffraction and the identification and analysis of clay minerals. In X-ray Diffraction and the Identification and Analysis of Clay Minerals; Oxford University Press: Oxford, UK, 1989.

52. Starkey, H.C.; Blackmon, P.D.; Hauff, P.L. The Routine Mineralogical Analysis of Clay-Bearing Samples; United States Government Publishing Office: Washington, DC, USA, 1984.

53. Warr, L.N.; Rice, A.H.N. Interlaboratory Standardization and Calibration of Day Mineral Crystallinity and Crystallite Size Data. J. Metamorph. Geol. 1994, 12, 141-152. [CrossRef]

54. Kübler, B. La Cristallinite de l'illite et Les Zones Tout a Fait Superieures Du Metamorphisme. In Etages Tectoniques; van Bemmelen, R.W., Chapman, C.A., Watznauer, A., Eds.; La Baconniere: Boudry, Switzerland, 1981; pp. 105-121.

55. Warr, L.N.; Mählmann, R.F. Recommendations for Kübler Index Standardization. Clay Minerals 2015, 50, 283-286. [CrossRef]

56. Winkler, H.G.F. Anatexis, Formation of Migmatites, and Origin of Granitic Magmas. In Petrogenesis of Metamorphic Rocks; Winkler, H.G.F., Ed.; Springer Study Edition; Springer: New York, NY, USA, 1979; pp. 283-339. ISBN 978-1-4757-4215-2.

57. Tilley, C.E. A Preliminary Survey of Metamorphic Zones in the Southern Highlands of Scotland. Q. J. Geol. Soc. 1925, 81, 100-112. [CrossRef]

58. Barrow, G. On an Intrusion of Muscovite-Biotite Gneiss in the South-Eastern Highlands of Scotland, and Its Accompanying Metamorphism. Q. J. Geol. Soc. 1893, 49, 330-358. [CrossRef]

59. Merriman, R.J.; Frey, M. Patterns of very low-grade metamorphism in metapelitic rocks. In Low-Grade Metamorphism; Frey, M., Robinson, D., Eds.; Blackwell Publishing Ltd.: Oxford, UK, 1998; pp. 61-107. ISBN 978-1-4443-1334-5.

60. Abad, I. Physical meaning and applications of the Illite Kübler index: Measuring reaction progress in low-grade metamorphism. In Diagenesis and Low-Temperature Metamorphism, Theory, Methods and Regional Aspects; Sociedad Española de Mineralogía: Jaén, Spain, 2007; pp. 53-64. 
61. Ledésert, B.; Hébert, R.L.; Grall, C.; Genter, A.; Dezayes, C.; Bartier, D.; Gérard, A. Calcimetry as a Useful Tool for a Better Knowledge of Flow Pathways in the Soultz-Sous-Forêts Enhanced Geothermal System. J. Volcanol. Geotherm. Res. 2009, 181, 106-114. [CrossRef]

62. Dullien, F.A.L. Porous Media: Fluid Transport and Pore Structure; Academic Press: San Diego, CA, USA, 1979; ISBN 978-0-323-13933-5.

63. Navelot, V.; Géraud, Y.; Favier, A.; Diraison, M.; Corsini, M.; Lardeaux, J.-M.; Verati, C.; Mercier de Lépinay, J.; Legendre, L.; Beauchamps, G. Petrophysical Properties of Volcanic Rocks and Impacts of Hydrothermal Alteration in the Guadeloupe Archipelago (West Indies). J. Volcanol. Geotherm. Res. 2018, 360, 1-21. [CrossRef]

64. Gates, W.P.; Nefiodovas, A.; Peter, P. Permeability of an Organo-Modified Bentonite to Ethanol-Water Solutions. Clays Clay Miner. 2004, 52, 192-203. [CrossRef]

65. Bard, J.P. Microtextures des Roches Magmatiques et Métamorphiques; Masson: Paris, France, 1980.

66. Goldich, S.S. A Study in Rock-Weathering. J. Geol. 1938, 46, 17-58. [CrossRef]

67. Que, M.; Allen, A.R. Sericitization of Plagioclase in the Rosses Granite Complex, Co. Donegal, Ireland. Mineral. Mag. 1996, 60, 927-936. [CrossRef]

68. Streckeisen, A.; Le Maître, R.W. A Chemical Approximation to Modal QAPF Classification of the Igneous Rocks. Neues Jahrb. Mineral. Abh. 1979, 136, 169-206.

69. Beaufort, D.; Baronnet, A.; Lanson, B.; Meunier, A. Corrensite; a Single Phase or a Mixed-Layer Phyllosilicate in Saponiteto-Chlorite Conversion Series? A Case Study of Sancerre-Couy Deep Drill Hole (France). Am. Mineral. 1997, 82, 109-124. [CrossRef]

70. Jagodzinski, H. Eindimensionale Fehlordnung in Kristallen und ihr Einfluss auf die Röntgeninterferenzen. I. Berechnung des Fehlordnungsgrades aus den Röntgenintensitäten. Acta Cryst. 1949, 2, 201-207. [CrossRef]

71. Cox, K.G. The Interpretation of Igneous Rocks; Springer Science \& Business Media: London, UK, 1979; ISBN 978-94-017-3373-1.

72. Wilson, M. Review of Igneous Petrogenesis: A Global Tectonic Approach. Terra Nova 1989, 1, 218-222. [CrossRef]

73. Jensen, L.S. A New Plot for Classifying Subalkalic Volcanic Rocks. Ont. Div. Mines Misc. Pap. 1976, 66, 1-22.

74. White, A.J.R.; Chappell, B.W. Granitoid types and their distribution in the Lachlan Fold Belt, southeastern Australia. In Geological Society of America Memoirs; Geological Society of America: Boulder, CO, USA, 1983; Volume 159, pp. 21-34, ISBN 978-0-8137-1159-1.

75. Le Maître, R.W.; Bateman, P.; Dudek, A.; Keller, J.; Lameyre Le Bas, M.J.; Sabine, P.A.; Schmid, R.; Sorensen, H.; Streckeisen, A.; Woolley, A.R.; et al. A Classification of Igneous Rocks and Glossary of Terms; Blackwell: Oxford, UK, 1989.

76. Rollinson, H.R. Using Geochemical Data: Evaluation, Presentation, Interpretation; Routledge: Abingdon, UK, 1993; ISBN 978-1-31789819-1.

77. Boynton, W.V. Cosmochemistry of the rare earth elements: Meteorite studies. In Developments in Geochemistry; Elsevier: Amsterdam, The Netherlands, 1984; Volume 2, pp. 63-114. ISBN 978-0-444-42148-7.

78. McDonough, W.; Sun, S.-S.; Ringwood, A.; Jagoutz, E.; Hofmann, A. Potassium, Rubidium, and Cesium in the Earth and Moon and the Evolution of the Mantle of the Earth. Geochim. Cosmochim. Acta 1992, 56, 1001-1012. [CrossRef]

79. Sun, S.; McDonough, W.F. Chemical and Isotopic Systematics of Oceanic Basalts: Implications for Mantle Composition and Processes. Geol. Soc. Lond. Spec. Publ. 1989, 42, 313-345. [CrossRef]

80. Koljonen, T.; Rosenberg, R.J. Rare Earth Elements in Granitic Rocks. Lithos 1974, 7, 249-261. [CrossRef]

81. Alderton, D.H.M.; Pearce, J.A.; Potts, P.J. Rare Earth Element Mobility during Granite Alteration: Evidence from Southwest England. Earth Planet. Sci. Lett. 1980, 49, 149-165. [CrossRef]

82. Li, X.-C.; Fan, H.-R.; Santosh, M.; Hu, F.-F.; Yang, K.-F.; Lan, T.-G. Hydrothermal Alteration Associated with Mesozoic GraniteHosted Gold Mineralization at the Sanshandao Deposit, Jiaodong Gold Province, China. Ore Geol. Rev. $2013,53,403-421$. [CrossRef]

83. Warr, L.N.; Cox, S.C. Correlating Illite (Kübler) and Chlorite (Árkai) “Crystallinity” Indices with Metamorphic Mineral Zones of the South Island, New Zealand. Appl. Clay Sci. 2016, 134, 164-174. [CrossRef]

84. Fulignati, P. Clay Minerals in Hydrothermal Systems. Minerals 2020, 10, 919. [CrossRef]

85. Creasey, S.C. Hydrothermal alteration. In Geology of the Porphyry Copper Deposits Southwestern North America; Titley \& Hicks: Tucson, AZ, USA, 1966; pp. 51-74.

86. Traineau, H.; Genter, A.; Cautru, J.P.; Fabriol, H.; Chevremont, P. Petrography of the Granite Massif from Drill Cutting Analysis and Well Log Interpretation in the Geothermal HDR Borehole GPK1 (Soultz, Alsace, France). Geotherm. Sci. Technol. 1991, 3, 1-29.

87. Środon, J. Nature of Mixed-Layer Clays and Mechanisms of Their Formation and Alteration. Annu. Rev. Earth Planet. Sci. 1999, 27, 19-53. [CrossRef]

88. Genter, A. Géothermie Roches Chaudes Sèches: Le Granite de Soultz-Sous-Forêts (Bas-Rhin, France): Fracturation Naturelle, Altérations Hydrothermales et Interaction Eau-Roche. Ph.D. Thesis, Université d'Orléans, Orléans, France, 1989.

89. Burnham, C.W. Facies and Types of Hydrothermal Alteration. Econ. Geol. 1962, 57, 768-784. [CrossRef]

90. Velde, B. Clays and Clay Minerals in Natural and Synthetic Systems; Development in Sedimentology; Elsevier: Amsterdam, The Netherlands, 1977; ISBN 978-0-08-086933-9.

91. Steiner, A. Clay Minerals in Hydrothermally Altered Rocks at Wairakei, New Zealand. Clays Clay Miner. 1968, 16, 193-213. [CrossRef]

92. Ledésert, B.; Hebert, R.; Genter, A.; Bartier, D.; Clauer, N.; Grall, C. Fractures, Hydrothermal Alterations and Permeability in the Soultz Enhanced Geothermal System. Comptes Rendus Geosci. 2010, 342, 607-615. [CrossRef] 
93. Vidal, J.; Patrier, P.; Genter, A.; Beaufort, D.; Dezayes, C.; Glaas, C.; Lerouge, C.; Sanjuan, B. Clay Minerals Related to the Circulation of Geothermal Fluids in Boreholes at Rittershoffen (Alsace, France). J. Volcanol. Geotherm. Res. 2018, 349, 192-204. [CrossRef]

94. Ledésert, B.A.; Hébert, R.L. How Can Deep Geothermal Projects Provide Information on the Temperature Distribution in the Upper Rhine Graben? The Example of the Soultz-Sous-Forêts-Enhanced Geothermal System. Geosciences 2020, 10, 459. [CrossRef]

95. Sardini, P.; Ledésert, B.; Touchard, G. Quantification of microscopic porous networks by image analysis and measurements of permeability in the Soultz-Sous-Forêts Granite (Alsace, France). In Fluid Flow and Transport in Rocks: Mechanisms and Effects; Jamtveit, B., Yardley, B.W.D., Eds.; Springer: Dordrecht, The Netherlands, 1997; pp. 171-189. ISBN 978-94-009-1533-6.

96. Glaas, C.; Patrier, P.; Vidal, J.; Beaufort, D.; Genter, A. Clay Mineralogy: A Signature of Granitic Geothermal Reservoirs of the Central Upper Rhine Graben. Minerals 2021, 11, 479. [CrossRef]

97. Meunier, A.; Velde, B.D.; Dudoignon, P.; Beaufort, D. Identification of Weathering and Hydrothermal Alteration in Acidic Rocks: Petrography and Mineralogy of Clay Minerals. Sci. Géologiques Bull. Mémoires 1983, 72, 93-99.

98. Tardy, Y.; Paquet, H.; Millot, G. Trois modes de genèse des montmorillonites dans les altérations et les sols. Bull. Groupe Français Argiles 1970, 22, 69-77. [CrossRef]

99. Liu, Y.; Xie, C.; Li, C.; Li, S.; Santosh, M.; Wang, M.; Fan, J. Breakup of the Northern Margin of Gondwana through Lithospheric Delamination: Evidence from the Tibetan Plateau. GSA Bull. 2018, 131. [CrossRef]

100. Chambefort, I.; Moritz, R.; von Quadt, A. Petrology, Geochemistry and U-Pb Geochronology of Magmatic Rocks from the High-Sulfidation Epithermal Au-Cu Chelopech Deposit, Srednogorie Zone, Bulgaria. Miner. Depos. 2007, 42, 665-690. [CrossRef]

101. Garrels, R.M.; MacKenzie, F.T. Origin of the Chemical Compositions of Some Springs and Lakes. In Equilibrium Concepts in Natural Water Systems; Advances in Chemistry; American Chemical Society: Washington, DC, USA, 1967; Volume 67, pp. 222-242, ISBN 978-0-8412-0068-5.

102. Rosener, M.; Géraud, Y. Using Physical Properties to Understand the Porosity Network Geometry Evolution in Gradually Altered Granites in Damage Zones. Geol. Soc. Lond. Spec. Publ. 2007, 284, 175-184. [CrossRef]

103. Cassiaux, M.; Proust, D.; Siitari-Kauppi, M.; Sardini, P.; Leutsch, Y. Clay Minerals Formed during Propylitic Alteration of a Granite and Their Influence on Primary Porosity: A Multi-Scale Approach. Clays Clay Miner. 2006, 54, 541-554. [CrossRef]

104. White, A.F.; Schulz, M.S.; Lowenstern, J.B.; Vivit, D.V.; Bullen, T.D. The Ubiquitous Nature of Accessory Calcite in Granitoid Rocks: Implications for Weathering, Solute Evolution, and Petrogenesis. Geochim. Cosmochim. Acta 2005, 69, 1455-1471. [CrossRef] 